This draft: November 2008

\title{
The Internal Governance of Firms ${ }^{1}$
}

\author{
Viral V. Acharya \\ LBS, NYU and CEPR
}

\author{
Stewart Myers \\ MIT and NBER
}

\author{
Raghuram Rajan \\ GSB Chicago and NBER
}

We develop a model of internal governance where the self-serving actions of top management are limited by the potential reaction of subordinates. We find that internal governance can mitigate agency problems and ensure firms have substantial value, even without any external governance. Internal governance seems to work best when both top management and subordinates are important to value creation. We then allow for governance provided by external financiers and find situations where external governance, even if crude and uninformed, complements internal governance in improving efficiency. Interestingly, this allows us to develop a theory of dividend policy, where dividends are paid by self-interested CEOs to maintain a balance between internal and external control. Finally, we explore how the internal organization of firms may be structured to enhance the role of internal governance. Our paper could explain why young firms with limited external oversight, and firms in countries with poor external governance, can have substantial value, and why improving external governance may not be a panacea for all governance problems.

\footnotetext{
${ }^{1}$ We thank Franklin Allen, Effi Benmelech, Douglas Diamond, Milton Harris, Roni Kisin, Amit Seru, Luigi Zingales and seminar participants at Berkeley, Chicago Booth, Michigan State, NYU-Stern for very helpful conversations and comments. Rajan acknowledges support from the Center for Research on Securities Prices at the University of Chicago and the Initiative on Global Markets.
} 
The common view of the public corporation is that of an organization run by top managers, and monitored by a board of directors on behalf of public shareholders. The separation of decision management (the CEO) from decision control (the board) and from risk-bearing (public shareholders) is thought of as a reasonable way to structure firm governance (see Fama and Jensen (1983 a b), Jensen (2000)), and so long as decisions are made in the interests of the residual claimants, efficiency is maximized.

Yet the clear evidence that the public corporation has survival value has to be set against the equally clear evidence that most shareholders have little control over boards (see, for example, Monks (2007)), that many boards are poorly informed and have little ability to scrutinize top management's decisions (see, for example, Mace (1971)), and some CEOs are self interested rather than working for shareholders (see, for example, Jensen (1986, 1993), Morck, Shleifer and Vishny (1989), and Shleifer and Vishny $(1989,1997))$. Admittedly, the market for corporate control can offer some discipline, but it is hard to see it as effective in controlling operational decisions. How then do we reconcile the survival, and hence presumed efficiency, of the public corporation with the ineffectiveness of the supposed channels through which it is governed?

We will argue in this paper that there are important stakeholders in the firm, such as critical employees, who care about its future even if the CEO has short horizons and is selfinterested and shareholders are dispersed and powerless. These stakeholders, because of their power to withdraw their contributions to the firm, can force a self-interested myopic CEO to act in a more public spirited and far-sighted way. We call this process "internal governance".

The main departure of this paper from much of the existing literature is to not treat the firm as a monolithic single-employee entity, but to see it as composed of diverse agents with different horizons, different opportunities for misappropriation or growth, and different interests. To fix ideas, think of a partnership run by an old CEO who is about to retire, and who has a young manager working under him. Three ingredients go into producing the firm's current cash 
flows. First, the firm's capital stock, which could be the firm's stock of physical capital (machines), or organizational capital (networks), or relationship capital (client relationships); Second, the CEO's ability to manage the firm based on his talent and his knowledge of its specific problems; Third, the young manager's effort, which allows her to learn to deal with the firm's specific issues.

We assume the cash flow is unverifiable as produced. However, the CEO can put in place internal audit and accounting mechanisms that would make a pre-determined portion of the cash flows verifiable, and ensure they are channeled into investment. ${ }^{2}$ The CEO can appropriate the cash flow that remains unverifiable - more generally, he can consume perks, "tunnel" cash out of the firm through self-dealing, or even not generate the cash by shirking on the job.

Note that because the CEO has a short horizon, he could simply decide to appropriate all the cash. However, in order to generate the cash in the first place he needs the young manager to put in effort. If she sees little future in the firm because the CEO invests nothing, the young manager will have little incentive to exert effort in management and on-the-job learning. This will reduce cash flows considerably. To forestall this, the CEO will commit to investing some fraction of the cash flows in order to preserve a future for his young employee, thereby motivating her. Intuitively, the need to motivate employees forces the CEO to invest, and thus leave a portion of the cash flows behind when he departs the firm. ${ }^{3}$ This allows the firm to build substantial amounts of capital stock and value, despite being led by a sequence of myopic and rapacious CEOs.

We show that internal governance is most effective when neither the CEO nor the manager dominate in contributions to the firm's cash flows. Intuitively, if the CEO dominates, he has no desire to provide incentives for the manager. If the manager's contributions dominate, the

\footnotetext{
${ }^{2}$ They could also be paid out as dividends, but we will come to this later.

${ }^{3}$ It is hard to write contracts with the CEO on investment since both the quantity and quality of investment should depend on business conditions, and the CEO's business judgment, all of which are hard to specify ex ante. Managerial learning effort is equally hard to contract upon, though it can be rewarded ex post through promotion (see Prendergast (1993)).
} 
manager has little incentive to learn because she cannot appropriate cash flows today, and the learning will be of little use when she does become CEO and can appropriate cash flows. Also, because both contemporaneous and forward looking elements of the business environment matter for participant incentives, internal governance works best when the business environment is stable.

Indeed, in this framework it may not make sense to strengthen external institutions such as courts so as to increase the costs of appropriation (for example, by increasing the propensity of courts to investigate and punish such appropriation). One might think that this would make the CEO more willing to invest at the margin because his cost of appropriation would have increased. However, because the manager no longer sees as many rents in the future, her incentive to exert effort can fall, and the CEO's desire to invest in order to incentivize that effort can also fall. ${ }^{4}$ Overall efficiency can be reduced dramatically.

There may, however, be merit in some forms of external control exercised by investors. We have implicitly assumed so far that the firm's capital stock is in intangible assets such as the human capital of employees or client relationships, which cannot be seized or sold. But what if the investment were instead in tangible assets, such as machines or land, which could be seized and sold? This would then offer a role for outside equity, and would allow the firm to be structured as a public corporation.

To see this, we assume that, in the spirit of Myers (2000), outside equity has the capacity (through the board of directors) to periodically exercise its fairly crude ownership right of taking over control of the assets. Outside equity thus has no direct effect over the investment or effort decision - it has no operational influence. Even so, it turns out that the act of going public followed by the exercise of even these crude control rights can greatly enhance investment by the $\mathrm{CEO}$ and the value of the firm. In our framework, the improvement is not because outside equity

\footnotetext{
${ }^{4}$ This point is reminiscent of Shleifer and Summers (1988), but their focus was on raiders breaking implicit contracts in the firm and thus transferring value.
} 
monitors the actions of the CEO, but primarily because equity holders are indifferent between being paid in cash or being "paid" via [the control rights inherent in] a higher capital stock. For the CEO, the dollar paid out as dividends and the dollar left behind as investment costs the same, but the CEO prefers to "pay" by investing to increase capital stock because this will have the collateral effect of motivating greater effort by the manager. This could explain the reluctance of firms to pay dividends, even when returns on investment are not great.

Eventually, though, as the rate of return on capital falls, by investing more capital the CEO could make the manager worse off, because he increases the capacity of outside equity to extract value by more than he increases the capacity of the manager to generate cash (net of this period's effort cost) as CEO next period. This is when the current CEO will switch to paying dividends - not because of the pressures exerted by outside equity alone, but because more investment will de-motivate managers. This then gives us a dividend policy in firms run by selfinterested CEOs that corresponds to the life cycle of a firm and its investment policy, with dividends not being paid when the firm is young and investment profitable, and dividends being paid when the firm is mature.

Interestingly, this combination of internal and external governance can eliminate the rents extracted by management, even though equity's control rights are so crude. Other forms of providing incentives do not always fare so well. We examine whether giving the CEO equitybased compensation can improve matters. It turns out that under a variety of circumstances, it does not - interestingly, the limited control rights possessed by outside equity imply that equity values do not reflect the entirety of cash flows produced by the firm. Indeed, the dictum to maximize equity value may offer little relevant guidance in such firms.

Finally, the way the firm is structured internally can influence the process of internal governance. Indeed, one of the roles of the venture capitalist in young firms may be to choose the allocation of work between the CEO and subordinate managers appropriately so as to make the firm governable (see Hellman and Puri (2002). Also, when there is more than one subordinate, 
other aspects of internal organization, such as the nature of competition between subordinates to succeed the CEO, can enhance the effectiveness of internal governance. Indeed, we only touch on the range of possible interesting interactions between internal organization and internal governance.

Our point, more generally, is that the traditional description of the firm in the first paragraph falls short on three counts. First, control need not be exerted just top down, or from outside, it can also be asserted bottom-up. Put differently, the CEO has to give his subordinates a reason to follow, and this, implicitly, is how they control him. Second, the view that there is one residual claimant in the firm, the shareholder, is probably too narrow. Anyone who shares in the quasi-rents generated by the firm has some residual claims and thus there is no easy equivalence between maximizing shareholder value and maximizing efficiency. Third, the fact that different parties have claims to different residual rents at different horizons means each one has to pay attention to others' residual claims in order to elicit co-operation. The checks that parties inside the firm impose on each other ensure the firm functions reasonably well, even if outside control is weak.

While our CEO is myopic and self interested, in reduced form he appears to act as if he cares about his subordinates and the survival of the firm. Indeed, Donaldson and Lorsch (1983) suggest from their interviews of top CEOs that continuity of the firm, rather than maximizing shareholder value, appears to be the primary stated objective of CEOs. Of course, most CEOs are not the caricatures that economic models like ours make them out to be, yet it is reassuring that even though we imbue them with no redeeming qualities, the model still has them doing reasonably good things for the firm.

The model can be applied to answer a variety of questions, ranging from why stocks in countries with poor minority investor protection have non-negligible value, to when firms are most likely to overinvest, and when firms ought to go public or private. It also offers some novel implications, for example on the relative importance of external governance in firms with a young 
CEO or workforce versus its importance in firms with an older CEO or workforce. It could even be applied to improve our understanding of the recent breakdown of internal governance in financial firms.

Our work suggests that perhaps then one should think of the firm less as a top-down hierarchy led by a board-monitored CEO, and more as a restricted market where it is not from the benevolence of the participants that we expect value creation but from the checks and balances they impose on each other in furthering their own interest. Implicit in our framework is, therefore, a theory of the firm and its boundaries. In our view, the firm is an agglomeration of assets and specialized human capital which give it unique capabilities (see, for example, Penrose (1959), Grossman and Hart (1986), Hart and Moore (1990), and Rajan and Zingales (1998, 2001)). The literature suggests the ability to control access to the rents the firm generates is top management's source of control. In this paper, we focus on the "bottom-up" influence over firm actions, exercised by those who have access but do not yet have explicit control, because of their ability to affect the firm's rents. More generally, internal checks and balances may be an important, and under-researched, aspect of firm governance.

Our paper relates to important work by Fama and Jensen (1983 a and b), Allen and Gale (2000) and Landier, Sraer, and Thesmar (2006,2008). We will explain the connections once we lay out the basic model. The rest of the paper is as follows. In section I, we present the framework for a simple model; in section II, we solve it and analyze different outcomes. We then explore the role of dispersed outside equity in section III, and discuss extensions of the model, especially to internal organization issues, in section IV. We conclude with a discussion of the empirical implications of the model. 


\section{The model}

Consider a firm with a two-level managerial hierarchy. At the top of the managerial hierarchy is a CEO who is old. In the second layer is a manager who is young. Each agent can work, at most, for 2 periods.

The cash flow generated by the firm is unverifiable to begin with. At the beginning of each period t, the current $\mathrm{CEO}$ decides the internal audit and accounting procedures to put in place. More comprehensive procedures allow more of the cash flows the firm generates to be made verifiable and applied to investment (later, we will examine the choice between applying these cash flows to investment and to payments to external claim holders). Thus the current CEO can determine what the firm's end-of-period capital stock, $k_{t}$, will be. The manager then decides how much he will engage in firm specific learning effort, $s_{t}$, at a personal cost of $s_{t}$.

\subsection{Learning by doing}

Firm-specific learning is important for a manager to be effective - in a consumer product firm, for example, it may entail visiting vendors and the customers in the market repeatedly and understanding the ways they buy and use the product. Not only does such learning help generate business and contribute to firm cash flows when the manager is young (it is thus a form of effort and we will use the terms "learning" and "effort" interchangeably), it also helps him make better decisions if he is made $\mathrm{CEO}$ - for even though such knowledge may be critical for the CEO to function effectively, it may be much harder to acquire at the CEO level where vendors and customers will be far more circumspect, and the CEO's time more limited. ${ }^{5}$ More specifically, at the end of any period $t$, the firm generates cash flows

$$
C_{t}\left(k_{t-1}, s^{C E O}, s_{t}\right)=\theta_{t}\left(k_{t-1}\right)^{\gamma}\left[f\left(s^{C E O}\right)+g\left(s_{t}\right)\right]
$$

\footnotetext{
${ }^{5}$ The literature has called such learning "organizational capital" (Atkeson and Kehoe, 2005, and Lustig, Syverson and Nieuwerburgh, 2008, being some recent examples).
} 
$\theta_{t}$ is a measure of how favorable the business environment is at time $t$ for generating cash flows, and $\gamma$ is a constant less than one. Function $f$ indicates the CEO's contribution to cash flows, and its argument, $s^{C E O}$, is the firm-specific learning acquired by the $\mathrm{CEO}$ when he was a young manager (that is, in period t-1). Function $g$ captures the manager's contribution to cash flows, with $s_{t}$ being the learning effort the manager exerts at time t. Both $f$ and $g$ are increasing and concave. All agents maximize the present discounted value of their remaining lifetime income. The discount rate applied to next period's cash flows is $(1+\mathrm{r})$.

\subsection{Appropriation}

We assume employee wages are normalized to zero. We also assume an extreme form of agency problem to fix ideas; The CEO appropriates the cash flow that is not made verifiable, that is, he appropriates cash flow-investment $=C_{t}-\left(k_{t}-k_{t-1}\right)=C_{t}+k_{t-1}-k_{t}{ }^{6}$

At the end of every period, the current CEO retires, so he has no direct incentive to preserve firm value for the future. The next CEO is the current manager, who is the only one with the necessary human capital to succeed. We will later examine more detailed models of CEO selection.

\subsection{Timing.}

Critical in what follows is that the CEO will determine the portion of cash flows he will make verifiable (and thus the firm's investment) before the manager engages in learning effort. In practice, the steps may be more incremental. The CEO will articulate his investment strategy (e.g., investing in China) and will take the incremental actions consistent with that vision. For instance, he could order the capital equipment, arrange for the land, or hire new workers (all to be

\footnotetext{
${ }^{6}$ It is most convenient, mathematically speaking, to allow the CEO to choose the end-of-period capital stock $k_{t}$ rather than (net) investment $=k_{t}-k_{t-1}$. However, it is possible that net investment could be negative. A high (un-modeled) depreciation rate for old capital will allow us to have a declining capital stock even with positive gross investment. Alternatively, we have to allow for the possibility that some portion of the old capital stock is also unverifiable, which allows the CEO to set the new capital stock below the level of the old. We will ignore this complication in what follows, though it is easily handled.
} 
paid for out of cash flow). The manager will respond to each incremental action with incremental effort. It is natural, therefore, to think of the CEO's commitment to the investment strategy as coming first in a leader-follower relationship. ${ }^{7}$ The timing each period then is

Period $\mathrm{t}$

Period $\mathrm{t}+1 \ldots$

\begin{tabular}{|l|l|l|l|l|}
\hline $\begin{array}{l}\text { CEO hires } \\
\text { manager. }\end{array}$ & $\begin{array}{l}\text { CEO commits } \\
\text { to end-of- } \\
\text { period capital } \\
\text { stock } k_{t}\end{array}$ & $\begin{array}{l}\text { Manager } \\
\text { engages in } \\
\text { learning effort } \\
s_{t}\end{array}$ & $\begin{array}{l}\text { Cash generated. } \\
\text { Investment } \\
\text { made. CEO } \\
\text { gets residual. }\end{array}$ & $\begin{array}{l}\text { CEO } \\
\text { retires. } \\
\text { Manager } \\
\text { becomes } \\
\text { CEO. }\end{array}$ \\
\hline
\end{tabular}

Figure 1: Timeline

\section{Outcomes}

We now solve the model and see what it implies for CEO investment and managerial effort.

\subsection{First best level of investment.}

Inspection suggests that the first best level of capital is

$$
k_{t}^{F B}=\left[\frac{\theta_{t+1}}{1+r}\left(f\left(s_{t}^{F B}\right)+g\left(s_{t+1}^{F B}\right)\right)\right]^{\frac{1}{1-\gamma}}
$$

where $s_{t}^{F B}, s_{t+1}^{F B}$ are first best levels of learning effort. ${ }^{8}$ Similarly, $s_{t}^{F B}$ solves

$$
\frac{\theta_{t+1}}{1+r}\left(k_{t}^{F B}\right)^{\gamma} f^{\prime}\left(s_{t}^{F B}\right)+\theta_{t}\left(k_{t-1}^{F B}\right)^{\gamma} g^{\prime}\left(s_{t}^{F B}\right)=1
$$

Thus the first-best level of investment increases with the prospective quality of the business environment, $\theta_{t+1}$, and importantly, does not directly depend on the current business environment

\footnotetext{
${ }^{7}$ Indeed, CEO's inability to deviate ex post from an investment path could also be viewed as an outcome of the monitoring, or more generally, internal governance, imposed by second-line managers. In alternate settings, such commitment may arise as "leadership" on part of a long-term CEO, attempting to coordinate actions of subordinates in a time-consistent manner (Bolton, Brunnermeier and Veldkarmp, 2008).

${ }^{8}$ Formally, the first-best solves for investment and managerial learning pairs $\left(k_{t}, s_{t}\right)$ for all $t$, so as to maximize the discounted sum of cash flows net of investment and managerial effort, where the net cash flow in period $t$ is given by $C_{t}\left(k_{t-1}, s_{t-1}, s_{t}\right)$, as in equation (1.1), minus $\left[\left(k_{t}-k_{t-1}\right)+s_{t}\right]$.
} 
$\theta_{t}$. In contrast, the first-best level of managerial learning depends both on the current as well as the future business environment since it affects current as well as future cash flows.

\subsection{Second best}

In the second best, there is no direct rationale for the current CEO to commit to invest any of the cash flow. Investment puts the cash flow beyond his reach and his limited horizon implies he will see none of the future returns from investment.

However, there is a kind of contemporaneous settling up because the CEO's investment affects the future income of his manager, and therefore their incentive to engage in learning effort, and thus the firm's cash flows, today. To see this simple point, start first by writing down the CEO's income. It is

$$
C_{t}\left(k_{t-1}, s^{C E O}, s_{t}^{S B}\right)-\left(k_{t}-k_{t-1}\right)=\theta_{t}\left(k_{t-1}\right)^{\gamma}\left[f\left(s^{C E O}\right)+g\left(s_{t}^{S B}\right)\right]-\left(k_{t}-k_{t-1}\right)
$$

where $s_{t}^{S B}$ is the manager's (second-best) equilibrium learning. Differentiating w.r.t. $k_{t}$, we see that the CEO's marginal net return from investing is

$$
\theta_{t}\left(k_{t-1}\right)^{\gamma} g^{\prime} \frac{d s_{t}^{S B}}{d k_{t}}-1
$$

The net return depends on current business conditions $\theta_{t}$ and capital stock $k_{t-1}$ because these determine the cash flow impact of any increase in the manager's learning effort induced by CEO investment. Critically, it also depends on $\frac{d s_{t}^{S B}}{d k_{t}}$ - how the manager's optimal learning effort varies with investment. Indeed, this sensitivity of effort to investment is the channel through which the CEO's investment feeds back into contemporaneous cash flows, and will be a central focus in what follows. To see how this is determined, first note the manager chooses $s_{t}^{S B}$ to maximize his future rents as CEO. That is, he maximizes

$$
\frac{1}{1+r}\left[\theta_{t+1}\left(k_{t}\right)^{\gamma}\left[f\left(s_{t}\right)+g\left(s_{t+1}\right)\right]-\left(k_{t+1}-k_{t}\right)\right]-s_{t} \text {. }
$$


Differentiating and setting equal to zero, we get

$$
\frac{\theta_{t+1}}{1+r}\left(k_{t}\right)^{\gamma} f^{\prime}\left(s_{t}^{S B}\right)=1
$$

So $s_{t}^{S B}=f^{\prime-1}\left(\frac{1+r}{\theta_{t+1}\left(k_{t}\right)^{\gamma}}\right)$. Since $f^{\prime}$ is decreasing, we see that, ceteris paribus, the less the

future is discounted or better the expected future environment, $\theta_{t+1}$, or more the capital stock $k_{t}$ the CEO leaves behind, the greater the learning.

Now totally differentiating the manager's first order condition (1.7) and rearranging,

$$
\frac{d s_{t}^{S B}}{d k_{t}}=\frac{-\gamma f^{\prime}}{k_{t} f^{\prime \prime}}
$$

which is positive, implying that even a myopic CEO has incentives to invest for the future in order to motivate his manager today. Further specialization of functions allows us to obtain closed form solutions.

\subsection{Specializing functions.}

Let $\alpha g=f$, that is for the same amount of learning, the contribution of the CEO to cash flows

is $\alpha$ times that of the managers. Further, let $f\left(s_{t}\right)=\frac{1}{b-1}\left(a+b s_{t}\right)^{\frac{b-1}{b}}$ with $a \geq 0$ and $b>1$.

Substituting these assumptions in (1.8), then (1.5), we get,

$$
k_{t}=\theta_{t}\left(k_{t-1}\right)^{\gamma} \frac{\gamma}{\alpha}\left(a+b s_{t}^{S B}\right)^{\frac{b-1}{b}}
$$

Substituting $f$ in (1.7) and rearranging, we get

$$
\left(a+b s_{t}^{S B}\right)^{\frac{1}{b}}=\frac{\theta_{t+1}}{1+r}\left(k_{t}\right)^{\gamma}
$$

This then gives us

$$
s_{t}^{S B}=\frac{-a}{b}+\frac{1}{b}\left(\frac{\theta_{t+1}}{1+r}\left(k_{t}\right)^{\gamma}\right)^{b}
$$

Note that given capital stock $k_{t}$, the manager's effort, $s_{t}^{S B}$, depends only on the future 
business environment and the end-of-period capital stock, even though it affects current cash flow. This is because the manager does not share in current period rents - his horizon is different. Of course, the current environment will affect his choice, but only through $k_{t}$. Substituting (1.10) in (1.9) and simplifying, we get

$$
k_{t}=\left[\frac{\gamma}{\alpha} \theta_{t}\left(\frac{\theta_{t+1}}{1+r}\right)^{b-1}\right]^{\frac{1}{1+\gamma-\gamma b}}\left(k_{t-1}\right)^{\frac{\gamma}{1+\gamma-\gamma b}}
$$

Interestingly, the business environment today, $\theta_{t}$, and beginning-of-period capital stock, $k_{t-1}$ influence the end-of-period capital stock, even though they have no effect on the returns produced by that capital stock (which are driven by $\theta_{t+1}$ ). The intuition is simple - end-of-period capital adds to the CEO's income only by enhancing his subordinate's learning by doing today. That, in turn, matters more for current cash flows if today's business environment is good or if current capital stock is high. Put another way, appropriating an additional dollar is more attractive for the CEO if today's environment is bad, or if the firm's capital stock is small, because the associated decline in effort by his employee does less absolute damage. Finally, the greater the relative contribution of the manager to cash flows, $\frac{1}{\alpha}$, the greater is the desire of the CEO to motivate learning effort by increasing investment.

Steady state

In steady state, $\theta_{t+1}=\theta_{t}=\theta^{S S}$ and the second best steady state $k_{t}=k_{t-1}=k^{S B}$. Substituting in (1.12), and simplifying, we get

$$
k^{S B}=\left[\frac{\gamma}{\alpha} \frac{\left(\theta^{S S}\right)^{b}}{(1+r)^{b-1}}\right]^{\frac{1}{1-\gamma b}}
$$

From (1.12) and (1.13) we have 


$$
\frac{k_{t}}{k^{S B}}=\left(\frac{k_{t-1}}{k^{S B}}\right)^{\frac{\gamma}{1+\gamma-\gamma b}}=\left(\frac{k_{0}}{k^{S B}}\right)^{\left(\frac{\gamma}{1+\gamma-\gamma b}\right)^{t}}
$$

Thus any initial capital stock converges to steady state if $b<\frac{1}{\gamma}$. Steady state managerial learning and cash flow net of investment and learning effort can also be calculated using equations (1.11) and (1.1).

In Figures $2 \mathrm{a}, 2 \mathrm{~b}$ and $2 \mathrm{c}$, we plot the convergence to the steady state of investment, managerial learning and net cash flow, respectively, for two initial conditions - one that has initial investment above the steady state and one that has below. This numerical example (and the ones to follow) employ benchmark parameter values $(1+\mathrm{r})^{-1}=0.95, \gamma=0.2,(b-1) / b=0.3, \alpha=$ $0.5, a=0$, and $\theta^{S S}=1$. As the plots reveal, convergence is almost fully achieved within five CEO tenure periods. Further, as is clear from equation (1.14) and the plots, the convergence rate is faster when the firm is farther from the steady state in its initial condition.

Comparison to the first-best steady state

We can also determine the steady state under the first best. Substituting the specific form for $f$ and $g$ in (1.2) and (1.3), simplifying and solving, we get

$$
k^{F B}=\left[\frac{\gamma}{\alpha}\left(\frac{\theta}{1+r}\right)^{b}\left(\frac{1+\alpha}{b-1}\right)\left(\frac{1+r+\alpha}{\alpha}\right)^{b-1}\right]^{\frac{1}{1-\gamma b}}
$$

Comparing the ratio of the second best steady state in (1.13) with the first best steady state capital

stock above, we get $\frac{k^{S B}}{k^{F B}}=\left[\frac{(1+r)}{\left(\frac{1+\alpha}{b-1}\right)\left(\frac{1+r+\alpha}{\alpha}\right)^{b-1}}\right]^{\frac{1}{1-\gamma b}}$ (1.16). It can be shown that the ratio in (1.16) is smaller than one. Note that (somewhat surprisingly) the ratio is independent of the steady state business conditions. Finally, as can be verified analytically and as also shown in 
Figure 3a, as $\alpha \rightarrow 0$ or $\alpha \rightarrow \infty$, the ratio in square brackets tends to zero, suggesting that the capital stock under the second best agency solution tends to zero relative to the first best level.

The intuition is interesting. $\alpha$ represents the relative importance of the CEO in generating cash flows. If $\alpha$ is very high, the CEO does not really need the manager's effort, and hence sees little need to invest. If $\alpha$ is very low, today's manager, who reaps the benefit of his effort only when he is CEO, sees little merit in exerting effort, because that effort will do little to enhance his future rents. Indeed it is easily seen the ratio is maximized at a positive, finite level of $\alpha$.

$$
\begin{aligned}
& \text { Turn next to cash flows. } \frac{C F^{S B}}{C F^{F B}}=\frac{\left(k^{S B}\right)^{\gamma}\left(1+\frac{1}{\alpha}\right) f\left(s^{S B}\right)}{\left(k^{F B}\right)^{\gamma}\left(1+\frac{1}{\alpha}\right) f\left(s^{F B}\right)} \text {. Substituting values }{ }^{9} \text {, we get } \\
& \qquad \frac{C F^{S B}}{C F^{F B}}=\left[\frac{(1+r)}{\left(\frac{1+\alpha}{b-1}\right)\left(\frac{1+r+\alpha}{\alpha}\right)^{\frac{\gamma b}{1-\gamma b}}}\right]^{\frac{\gamma-1}{\gamma b}}
\end{aligned}
$$

As with investments, the ratio of the agency-modulated second-best cash flow to the first best cash flow is smaller than one and independent of steady-state business condition. ${ }^{10} \mathrm{We}$ summarize this discussion in the following proposition.

Proposition 1: Under stable business conditions, second-best investment, managerial learning and cash flows are all smaller relative to their first-best counterparts. Further, the efficiency of the organization in generating cash flows, measured as ratio of cash flows under the second-best

${ }^{9}$ From (1.10), we get $f\left(s^{S B}\right)=\frac{1}{b-1}\left(\frac{\theta}{1+r}\left(k^{S B}\right)^{\gamma}\right)^{b-1}$. Similarly, we can show from (1.3) that $f\left(s^{F B}\right)=\frac{1}{b-1}\left(\frac{\theta}{1+r} \cdot \frac{1+r+\alpha}{\alpha}\left(k^{F B}\right)^{\gamma}\right)^{b-1}$.

${ }^{10}$ From an efficiency standpoint, it is more appropriate to focus on cash flows net of investment and managerial effort. It turns out that in this case too, the ratio of second-best outcome to the first-best is small when $\alpha$ tends to zero or infinity (for the same reasons) and maximized at an interior level of $\alpha$ (again, see Figure 3a). 
to those under the first-best, is maximized when the CEO's contribution to cash flows is neither too large nor too small relative to the manager's contribution.

Proof: Omitted (available upon request).

\subsection{Some implications}

We have shown that internal governance can be moderately effective in disciplining the CEO's actions, and ensuring the firm creates value. Even though the CEO cares only about today, while the manager cares only about the future, because of their mutual interdependence, they have the incentive to act in the broader interest. This is brought out starkly by Proposition 1, where once either party becomes irrelevant to the generation of cash flows, the second best solution becomes very inefficient relative to the first best.

Cash flow correlation with investment

Interestingly, internally-governed firms may naturally display a correlation ("sensitivity") between investments and current cash flows. The rationale is as follows. Managerial effort anticipates future business conditions and also responds to the CEO's current investments. Since the CEO's current investment is driven by the need to motivate effort so as to enhance current (not future) cash flows, it will be driven by current business conditions. Since current business conditions drive both cash flow and investment, there is a correlation between the two even after controlling for future business conditions.

To see this, we report in Figure $3 \mathrm{~b}$ the coefficients from regressing investment normalized by past capital stock $\left(i_{t} / k_{t-1}\right)$ on cash flows $\left(\right.$ Cashflow $\left._{t} / k_{t-1}\right)$ and business

conditions $\left(\theta_{t+1}\right)$, from a simulation of 500 periods around our benchmark example, where each period, business condition is drawn to be a random variable that is uniformly distributed $\left(\theta_{t+1} \sim \operatorname{Unif}[0.5,1.5]\right)$. The regression is designed to match closely the kind of regressions employed in the investment-cash flow sensitivity literature starting with Fazzari, Hubbard, and Peterson (1988). The figure shows that the sensitivity of investment to cash flows in our model is 
the highest when the relative importance of CEO $(\alpha)$ is low and declines monotonically as $\alpha$ increases. The intuition is that when $\alpha$ is low, managerial effort is the primary determinant of cash flow, and it responds positively to CEO-determined investment -- hence, the stronger correlation.

In our model, cash flows are sufficient to undertake investments. The correlation emerges not because firms are credit constrained (unlike Fazzari, Hubbard, and Peterson (1988)) but because of a common factor driving investments and cash flows. Indeed, Kaplan and Zingales (1997) suggest that it does not appear that many firms that have high cash flow investment correlations actually face financial constraints. Temporary shocks to business conditions

Better current business conditions increase the CEO's incentives to invest, even though they have no direct influence on the cash flows produced by the investment, because of the indirect effect they have on managerial incentives. Similarly, the current capital stock also alters investment incentives because it alters the value of eliciting managerial effort. If business conditions fluctuate a lot, especially in the downward direction, these dependencies may lead to significant inefficiencies.

As an illustration, consider Figure 3c wherein we retain all parameters as in the earlier cases but "shock" the business condition at date $\mathrm{t}=1$ to two possible values of $\theta_{1}=1.5$ or 0.5 compared to the steady-state value $\theta^{S S}=1$. Even though an unexpected temporary shock to business conditions should not affect investment for the future, as the plot shows, the investment in period $\mathrm{t}=1$ moves substantially (depending on the shock), taking about four CEO tenure periods to revert to the steady-state (once business conditions revert to the steady-state starting at $\mathrm{t}=2$ ). Intuitively, an adverse current shock to business conditions reduces current investment. This then reduces the capital stock next period, and reduces incentives to invest next period (and also managerial effort) even though business conditions have returned to normal. Thus shocks have 
persistence in our model of internal governance - recessions are likely to be more prolonged in economies where internal governance predominates.

If, however, business conditions are stable, the differing horizons of the CEO and the manager (the former focused on contemporaneous cash flows, the latter on future cash flows) could combine to make cash flows, appropriately sensitive to business conditions. This is what we see both in (1.16) and (1.17), where, in steady state, the ratio of second best to first best capital stock or cash flows do not depend on business conditions. It is in this sense that internal governance may work best when conditions are stable, rather than when conditions fluctuate (especially downwards) dramatically.

\subsection{Varying Assumptions}

Improvements in External Enforcement

What would happen if external institutions such as courts were strengthened so as to increase the costs of appropriation (for example, by increasing the propensity of courts to investigate and punish such appropriation). In the model, this is modeled by assuming the CEO expects to get only $\beta$ of the cash flows he appropriates (with $(1-\beta)$ of the cash flows being lost because of the defensive action he has to take vis a vis the police and courts). The CEO now maximizes $\beta\left[\theta_{t}\left(k_{t-1}\right)^{\gamma}\left[f\left(s^{C E O}\right)+g\left(s_{t}^{S B}\right)\right]-\left(k_{t}-k_{t-1}\right)\right]$ w.r.t. $k_{t}$. His marginal net return from investing is still $\theta_{t}\left(k_{t-1}\right)^{\gamma} g^{\prime} \frac{d s_{t}^{S B}}{d k_{t}}-1$, which is the same form as before because both his return from appropriation and his opportunity cost of investment are reduced by the same multiplier, $\beta$. The change comes in the manager's incentives, because she now maximizes $\frac{\beta}{1+r}\left[\theta_{t+1}\left(k_{t}\right)^{\gamma}\left[f\left(s_{t}\right)+g\left(s_{t+1}\right)\right]-\left(k_{t+1}-k_{t}\right)\right]-s_{t}$, and has a lower incentive to exert effort because future rents are lower. 
Indeed, for the functional form of $g$ and $f$ we have used earlier, we can show that the second best capital stock also falls as $\beta$ falls. ${ }^{11}$ Because the manager no longer sees as many rents in the future, her incentive to exert effort falls, and the CEO's desire to invest in order to incentivize that effort also falls. Thus in a world where internal governance is the primary source of managerial incentives, limiting rent extraction, for example through outside courts, can reduce overall value creating.

\section{Ownership}

Finally, we have been silent about who owns the capital stock (since the CEO appropriates everything, there are no residual cash flows apart from amounts invested in the capital stock). One view is that the capital stock consists of intangible or non-tradable assets such as human capital or relationships. In that case, what we have described is a partnership (with the CEO having control because of his superior ability to perform the functions of the CEO). An alternative view is that the assets are tangible and tradable, but they are owned by outside equity owners who have no control rights. We will shortly examine what happens when they do acquire control rights.

\section{The Power to Appoint}

We also have not examined the process by which managers are appointed. If there are substantial rents associated with being CEO, the appointing agent could well recoup these rents from managers when they are appointed by paying them below market wages. Alternatively, it may be that managers have no wealth at the time of appointment (and their salaries are too low, even collectively, for them to pay over time for the rents they would get as CEO). In that case, CEO appropriation is a pure rent going to those who are lucky enough to get into the firm. These

${ }^{11}$ It can be verified that $k_{t}=\left(\frac{\theta_{t+1} \beta}{(1+r)}\left(\frac{\theta_{t}\left(k_{t-1}\right)^{\gamma}}{\alpha}\right)^{\frac{1}{b-1}}\right)^{\frac{(b-1)}{(1-\gamma b+\gamma)}}$ and $s_{t}=\frac{1}{b}\left[-a+\left(\frac{\theta_{t+1} \beta\left(k_{t}\right)^{\gamma}}{(1+r)}\right)^{b}\right]$, both of which increase in $\beta$. 
different views matter when we consider the firm value that can go to outsiders. Under the first assumption, if outsiders control appointment, firm value is maximized when inefficiencies from investment distortion and effort distortion are minimized - CEO misappropriation is "paid for" up front and is thus irrelevant apart from the distortions it creates. Under the second assumption, CEO misappropriation is a cost to outside claimholders, in addition to the costs of the distortions it creates.

\subsection{Essential aspects of the mechanism of internal governance}

We have assumed external governance to be weak, that the CEO's objective function has no forward looking components, and that the CEO is self-interested - the future welfare of the firm or its employees has no weight in his objective function. All this can be relaxed.

But our goal is to see precisely what conditions are necessary for internal governance to work and to see where it could be an important support to corporate performance. Consider the necessary ingredients: the $\mathrm{CEO}$ should believe that undertaking a future-oriented action should increase current cash flows, and thus his take, today. Clearly, this requires key stakeholders to be interested in the future, even if the CEO is not. For instance, the airlines who buy from an airplane manufacturer would be most interested in its continued health (if nothing else, so that spare parts continue to be available), and would likely reduce their purchases if they saw too little investment. Exit by customers is therefore one source of discipline (see Hirschman (1970), Titman (1984)). Customers are, however, typically at a distance, and leaving aside the purchase of high value durable goods or large amounts of intermediate goods, are unlikely to be appropriately informed or concerned about a supplier's future health.

This then leaves employees as the stakeholders most concerned and most able to observe and do something about mismanagement. Again, whether they can be a reliable part of a mechanism of internal governance depends on whether they have a sizeable long term stake in the firm. This requires some firm-specific rents. The rents may come from some specific ability that is possessed only by top management that have served an apprenticeship inside the firm. The 
absence of such rents, either because external governance severely limits what senior management can appropriate, or because top management in the industry is interchangeable across firms, would render internal governance ineffective.

A second requirement for effective internal governance is that the actions the managers need to take to enhance current cash flows also contribute to acquiring future rents. ${ }^{12}$ If, for example, the actions are unrelated to the firm-specific rents because they are rewarded anyway in the market place - the manager works hard because performance can be observed by other firms, and they will pay more for a good performer - then the prospect of acquiring firm-specific rents will not motivate actions. Thus it is only if learning effort results in firm-specific knowledge that does not translate easily to other firms, or if effort leads to a greater prospect of within-firm promotion, that effort and rents will be linked. ${ }^{13}$

Also, the desired action by the CEO should lead to more learning effort by managers. Investment in our model is assumed to have that character. But one could envisage situations where weaker actions by the CEO lead to more compensating effort by the managers. What, for example, if managers greatly feared the opprobrium and the reputational taint associated with bad corporate performance? More underinvestment by the CEO might lead them to greater effort as they struggled to keep the firm out of bankruptcy. Of course, countries or situations where external governance is weak are also likely to be situations where the market inflicts few reputational penalties.

Finally, we have assumed that the CEO cannot force employees to produce the desired level of effort. However, this is not critical. As we will see later, even if managerial actions can

\footnotetext{
${ }^{12}$ We have assumed that the manager's effort also pays off directly in the future, since it determines his capability as CEO. This link is not strictly necessary. If the manager's effort is critical in generating the cash flow necessary to make the investment, then the manager's effort could be linked to the future via investment. We have not explored this link (we thank Mark Rubinstein for suggesting it).

${ }^{13}$ Employees could, of course, be mobile but not be able to monetize their learning - for instance, because it is firm-specific or because other firms cannot verify the quality or extent of the learning, and therefore hesitate to promote the imported employee into a leadership position. This would be sufficient for us to obtain the desired effects.
} 
be coerced so that incentives are not needed, internal discipline can be imposed on the CEO through the need to hire new employees.

In summary, the existence of future firm-specific rents can make employees far more effective in exerting internal governance. However, they do not do this by asserting voice (probably an easy way to get fired) in Hirschman's terminology, but by reducing effort or by being reluctant to join. None of this needs any coordination on the part of employees, or any appeal to the Board or to forces of outside control.

\subsection{Connections to the Literature}

Our model resembles Fama (1980) where concerns about the adverse reputational consequences of misappropriation on his post-retirement career keep the CEO on the straight and narrow. In contrast to the ex-post settling up in that model, the settling up in our model is contemporaneous and by parties whose interests are intimately involved - employees endogenously penalize excessive misappropriation. The difference is important, for instance in explaining the effects of capital structure.

We are, of course, not the first to analyze the phenomenon of internal governance. Fama and Jensen (1983 a and b) as well as Hansmann (1996) refer to mutual or internal monitoring, though they do not undertake a detailed analysis. Unlike Landier, Sraer, and Thesmar (2006), we do not appeal to the independence of top executives (as measured by their having preceded the CEO into the firm). Instead, we rely on their self interest - the fact that they typically have career concerns inside the firm. The mechanism through which they have impact is not through coordinated action or through appeal to a Board, but through their propensity to get de-motivated. This is neither exit nor voice, in the felicitous terminology of Hirschman (1970), nor active whistle-blowing as in Dyck, Morse and Zingales (2007), but an uncoordinated, even implicit, strike.

Our model of internal governance in a setting with overlapping generations of short-term CEO and managers vying for the CEO role next period is similar in spirit to the model sketched 
by Allen and Gale (2000, Chapter 12), though the details are quite different. Allen and Gale stress the role of complementarities between the CEO and managers in cash flow production (and hence the need for the CEO to elicit co-operation). This can lengthen the horizon of myopic decisionmakers. They appeal to the implications of such a model to explain and help understand the relative merits of the "stakeholder"-focus of governance of Japanese firms at one extreme and the "shareholder"-focus of Anglo-Saxon firms at the other extreme, with French and German firms somewhere in between. ${ }^{14}$

Similar to Allen and Gale (2000), Landier, Sraer, and Thesmar (2008) focus on situations where CEO and manager actions are complementary, and examine the role of optimal dissent in an organization. Intuitively, it is easier for a CEO to persuade the manager to follow him down the wrong path when they have similar private preferences over projects. Managers with different preferences would place greater constraints on the $\mathrm{CEO}$, but at the cost of them being less enthusiastic when the CEO's project choice correctly accords with his own preferences.

Unlike in both these models, the primary link between the CEO and managers in our model comes from investment. This allows us to explore a variety of additional issues including the life cycle of a firm and external governance. Let us now turn to these issues.

\section{Outside Equity}

Thus far, we have examined a simple model where outside capital plays no role in constraining top management. In particular, top management was constrained in its opportunism only by the rest of the organization. In practice, the CEO's actions will also be constrained by the product

\footnotetext{
${ }^{14}$ Allen, Carletti and Marquez (2007) study the effect of stakeholder capitalism in a setting where firms' concerns about employees and suppliers soften competition in product markets and enhance shareholder value. A model that is somewhat less related to ours in a modeling sense, but germane in an overall sense, is that of Kreps (1990) on the role played by reputation effects in lengthening decision-making horizons of myopic agents. Kreps considers a model where an overlapping set of managers co-operate, by mutually trusting each other, since a manager next period buys the reputational capital of the current manager and this keeps the current manager in check, preventing defections motivated by short-termism. In contrast to Kreps, our CEOs cannot sell the firm to subordinates.
} 
market (see Titman (1984) and Scharfstein (1988)), the capital market, and the market for corporate control. In what follows, we will focus on the capital market, leaving the disciplinary role of other markets in the context of our framework to future work. Interestingly, capital markets may not play as much of a role in "disciplining" the firm's management, as in moving the firm to a better equilibrium.

\subsection{Outside Equity}

We will examine outside equity, which has several interesting features, though our point can be made more generally for other forms of outside capital. To allow a role for external control, let us assume that the beginning-of-period capital stock consists of tangible assets that can be seized and sold by outside capital.

As before, we assume the CEO can make a commitment at the beginning of the period to make some portion of the cash flows verifiable. Now, though, he can use the verifiable portion not only to make investments but also to pay a dividend. Initially, it will be useful for notational convenience to assume he sets each amount separately, though we will later show that all that matters is he can commit to the total that is made verifiable, and his choice of how much to invest and how much to pay in dividends emerges endogenously.

Following Fluck (1998) and Myers (2000) we model outside equity holders, working through the board, as having a simple control right - the right to take the firm's capital stock at the beginning of each period if they believe the firm's announced dividend, $d_{t}$, out of cash flow is inadequate. In the beginning of period t, outside equity thus has the right to take $k_{t-1}$. It will leave the assets in for one more period if it gets an adequate return for leaving them in, that is, if $d_{t}+k_{t} \geq(1+r) k_{t-1}$ where $r$ is the required rate of return on equity. We first analyze the dividend and investment decisions of a going concern (where equity was issued in the past); then calculate the value of equity at IPO stage; then, we examine the CEO's investment decision at time of IPO; finally, we discuss the efficiency of outcomes under equity financing. 


\section{Going concern}

The new wrinkle is that when the CEO invests capital, he not only gives the manager more of an incentive to invest, he also gives outside equity a harder claim on the firm's cash flows. The enforceable payment to outsiders will reduce the manager's rent in the future. Therefore, we will need to pay attention to the manager's participation constraint now. Interestingly, from all this we will derive a theory of dividend policy.

The going concern CEO's maximization problem is

$$
\begin{gathered}
\max _{k_{t}, d_{t}} \theta_{t}\left(k_{t-1}\right)^{\gamma}\left[f\left(s^{C E O}\right)+g\left(s_{t}\right)\right]-\left(k_{t}-k_{t-1}\right)-d_{t}, \\
\text { s.t. } \quad k_{t}+d_{t} \geq(1+r) k_{t-1} \\
s_{t} \in \underset{\hat{s}_{t}}{\arg \max } \frac{1}{(1+r)}\left[\theta_{t+1}\left(k_{t}\right)^{\gamma}\left[f\left(\hat{s}_{t}\right)+g\left(s_{t+1}\right)\right]-\left(k_{t+1}-k_{t}\right)-d_{t+1}\right]-\hat{s}_{t} \\
\text { and } U\left(k_{t}\right)=\frac{1}{(1+r)}\left[\theta_{t+1}\left(k_{t}\right)^{\gamma}\left[f\left(s_{t}\right)+g\left(s_{t+1}\right)\right]-\left(k_{t+1}-k_{t}\right)-d_{t+1}\right]-s_{t} \geq 0 \quad \text { at }
\end{gathered}
$$

Differentiating the expected utility $U\left(k_{t}\right)$ of the manager w.r.t. $k_{t}$, we get

$U^{\prime}\left(k_{t}\right)=\frac{1}{1+r}\left[\theta \gamma k_{t}^{\gamma-1}\left(f\left(s_{t}\right)+g\left(s_{t+1}\right)\right)-r\right]+\frac{1}{1+r}\left[\theta k_{t}^{\gamma} f^{\prime}\left(s_{t}\right)-1\right] \frac{d s_{t}}{d k_{t}} .{ }^{15}$ The second

expression is zero (the Envelope Theorem), so $U^{\prime}\left(k_{t}\right)=\frac{1}{1+r}\left[\theta \gamma k_{t}^{\gamma-1}\left(f\left(s_{t}\right)+g\left(s_{t+1}\right)\right)-r\right]$.

The term in square brackets, which is the cash return on investment less the amount that has to be paid to outside equity, can be negative. Intuitively, a higher capital stock implies the manager puts in more effort, but it also requires the manager to pay equity more next period. If the returns on investment are sufficiently low, the manager's utility can be reduced by more capital stock. This should be contrasted with the earlier case where we had no outside equity (and hence no negative term in the square brackets), when more capital stock always increased the utility of the manager.

\footnotetext{
${ }^{15} \mathrm{We}$ are assuming here that $\left(k_{t+1}-k_{t}\right)+d_{t+1}=r k_{t}$, for this is the interesting case when $U\left(k_{t}\right)$ starts mattering.
} 
Let us now return to the CEO's maximization problem. Let $\lambda_{1}$ be the Lagrangian multiplier for the dividend constraint (1.19) and let $\lambda_{2}$ be the multiplier for the manager's participation constraint (1.21). The CEO's first order condition w.r.t. $d_{t}$ is

$$
-1+\lambda_{1}
$$

and w.r.t. $k_{t}$ is

$$
\theta_{t} k_{t-1}^{\gamma} g^{\prime} \frac{d s_{t}}{d k_{t}}-1+\lambda_{1}+\lambda_{2} U^{\prime}\left(k_{t}\right)
$$

Complementary slackness requires that

$$
\begin{gathered}
\lambda_{1}\left(k_{t}+d_{t}-(1+r) k_{t-1}\right)=0 \\
\lambda_{2} U\left(k_{t}\right)=0
\end{gathered}
$$

Now let us describe what this means for dividend policy and investment. First, if $k_{t} \geq(1+r) k_{t-1}$, then $\lambda_{1}=0$ (from (1.24)), which means that it does not make sense to pay dividends (from (1.22)). Intuitively, the capital stock left behind at the end of the period is more than enough to meet the equity holders' rate of return constraint, so they do not need to be paid more in dividends.

Second, when the manager's participation constraint $U\left(k_{t}\right)$ is satisfied with slack, $\lambda_{2}=0$ (from (1.25)). This means that the return for the CEO from satisfying the dividend constraint by increasing capital stock is $\theta_{t} k_{t-1}^{\gamma} g^{\prime} \frac{d s_{t}}{d k_{t}}-1+\lambda_{1}$, which beats the return for the CEO from paying more dividends, which is $-1+\lambda_{1}$ when $\frac{d s_{t}}{d k_{t}}>0$. Intuitively, "paying" equity holders by increasing capital stock versus paying with cash dividends costs the CEO the same dollar of cash flow, but the former is better because the manager has more incentive to put in effort whenever $\frac{d s_{t}}{d k_{t}}>0$ (which is always true in our framework so far). 
This is an important point. It means the CEO will not pay cash dividends, and will instead increase investments to meet the rate of return requirements of equity holders, provided the manager's participation constraint is met. In other words, in this region, $k_{t}=\operatorname{Max}\left[k_{t}^{S B},(1+r) k_{t-1}\right]$ where $k_{t}^{S B}$ is the capital stock the CEO would set in the absence of outside equity.

Finally, what happens when the intended capital stock becomes so high that the manager's participation constraint is just met, so that $U\left(k_{t}\right)=0$. From complementary slackness, $\lambda_{2}>0$. For well behaved functions (see below), the manager's expected rents $U\left(k_{t}\right)$ first increase in $k_{t}$ and then decrease as diminishing marginal returns set in. This implies that $U^{\prime}\left(k_{t}\right)<0$ when $U\left(k_{t}\right)=0$. The CEO will have to meet the manager's participation constraint by reducing the capital stock he sets at the end of the period, paying out $\operatorname{Max}\left[(1+r) k_{t-1}-k_{t}, 0\right]$ as dividends.

The point here is that as the rate of return on capital falls, by investing more capital the CEO could make the manager worse off, because he increases the capacity of outside equity to extract value by more than he increases the capacity of the manager to generate cash (net of this period's effort cost) as CEO next period. This is when the current CEO will switch to paying dividends.

For firms with well behaved expected utility for the manager (that is, $\lim _{k \rightarrow 0} U(k)>0$, $\lim _{k \rightarrow \infty} U(k)<0, U^{\prime \prime}(k)<0$, and $U^{\prime}(k)<0$ for some $\left.\mathrm{k}\right)$, and when the business environment is constant at $\theta_{t}=\theta \forall t$, we have

Proposition 2: In the presence of outside equity,

(i) The capital stock before the firm reaches steady state is $k_{t}=\operatorname{Max}\left[k_{t}^{S B},(1+r) k_{t-1}\right]$. 
(ii) The firm reaches steady state in period $\hat{t}$ when $\operatorname{Max}\left[k_{\hat{t}}^{S B},(1+r) k_{\hat{t}-1}\right] \geq \hat{k}$ where $\hat{k}$ is such that $U(\hat{k})=0$. The steady state capital stock is $\hat{k}$ in period $\hat{t}$ and after, and the steady state dividend is $\hat{d}=r \hat{k}$ in period $\hat{t}+1$ and after.

(iii) In period $\hat{t}$, the dividend is $\operatorname{Max}\left[\hat{k}-(1+r) k_{\hat{t}-1}, 0\right]$. The dividend before period $\hat{t}$ is zero.

Proof: Omitted.

The proposition then suggests the life cycle pattern of dividend payments and investment that has been empirically observed. In the early stages of a firm (when $k_{t}$ is low), the capital investment by the firm will be more than enough to meet the return expectations of equity investors. No dividends will be paid. As the firm becomes more mature and rates of return fall, the capital stock the CEO would desire to put in place in the absence of equity could fall below the level needed to meet equity's required rate of return. But now, the CEO will increase capital stock over the desired level instead of paying dividends because the higher capital stock has the collateral benefit of raising managerial effort. However, when capital stock is so high that raising it would violate the manager's participation constraint, the CEO will start paying out cash dividends, the capital stock will stabilize (when the business environment is stable), and future CEOs will all be at their participation constraint - they will get no excess rents. An Example

Let us go back to our example where $f\left(s_{t}\right)=\alpha g\left(s_{t}\right)=\frac{1}{b-1}\left(a+b s_{t}\right)^{\frac{b-1}{b}}$ with $a \geq 0$ and $b>1$ and $\gamma<\frac{1}{b}$. It is easily shown that $U^{\prime}\left(k_{t}\right)=\left[\frac{(\alpha+1) \theta_{t+1}^{b} \gamma}{\alpha(b-1)(1+r)^{b}} k_{t}^{\gamma b-1}-\frac{r}{1+r}\right]$, which is $\infty$ as $k_{t} \rightarrow 0$, and $-\frac{r}{1+r}$ as $k_{t} \rightarrow \infty$. Furthermore, $U^{\prime \prime}\left(k_{t}\right)<0$. Finally, 
$U\left(k_{t}\right)=\frac{1}{(1+r)}\left[\theta_{t+1}\left(k_{t}\right)^{\gamma}\left(1+\frac{1}{\alpha}\right) f\left(s_{t}\right)-r k_{t}\right]-s_{t}=\frac{a}{b}+\frac{\theta_{t+1}^{b} k_{t}^{\gamma b}(b+\alpha)}{(1+r)^{b} \alpha b(b-1)}-\frac{r k_{t}}{(1+r)}$, which is

$\frac{a}{b}$ as $k_{t} \rightarrow 0$, and $-\infty$ as $k_{t} \rightarrow \infty$. Since $U^{\prime}\left(k_{t}\right)$ is first positive, then negative, $U\left(k_{t}\right)$ first

increases from a positive number, then falls below zero, crossing zero at a single point. We can then map out dividend policy and investment for any set of parameters.

For the case $a=0$, we obtain $(\hat{k})^{1-\gamma b}=\frac{(b+\alpha) \theta^{b}}{\alpha b(b-1) r(1+r)^{b-1}}$. Comparing this to the first-best steady-state capital, we obtain that

$$
\left(\frac{\hat{k}}{k^{F B}}\right)^{1-\gamma b}=\frac{(b+\alpha)(1+r) \alpha^{b-1}}{\gamma b(1+\alpha)(1+r+\alpha)^{b-1}}
$$

which converges to zero as $\alpha$ goes to zero and to $\frac{(1+r)}{\gamma b}>1$ as $\alpha$ goes to infinity. Recall that

this is in contrast to the case without outside equity, when the ratio of second-best to first-best capital goes to zero at both these limits. The intuition is the same as before when $\alpha$ goes to zero - when only managerial effort is critical, the CEO cannot incentivize the manager through investment since the manager's effort will not pay off in the future when he does become CEO. But when managerial effort is not critical to current cash flows, the managerial participation constraint constrains the CEO less and less. The CEO then prefers to "pay" outside equity in capital, and outside equity "forces" the sequence of CEOs to grow the firm to a higher capital level before the firm reaches the steady state and starts paying cash dividends.

\section{Outside Equity Owned Firms and Rents}

Interestingly, in steady state, the $\mathrm{CEO}$ gets no rent in that his participation constraint is just met - he appropriates just enough after paying equity to compensate for his effort. But because he can appropriate all the cash flows at the margin, he has the maximum possible incentive to exercise effort. Indeed, if the firm cannot appropriate cash flows from the future, it cannot give him a better incentive scheme based on cash compensation, even if effort were verifiable. 
The reason why rents are reduced to zero, despite a succession of rapacious CEOs, is interesting. Each CEO cares only about his take, and about the manager only to the extent that it impacts managerial effort. By raising capital stock, the CEO raises managerial effort but also the capacity of outsiders to extract their due. Eventually, future CEO rent will fall, even while managerial effort keeps increasing, but the current CEO is not concerned - he is doing to his successor only what his predecessor did to him. The self interest of each CEO then ensures that rents are driven to zero, even though outsiders have only crude control rights.

\subsection{IPO}

Let us now see what happens earlier, when the CEO takes the firm public through an initial public offering (IPO) in period $\tau$. The above analysis implies that for a stable business environment $\theta$, there is a period $T$ at the end of which the value received by outside equity holders becomes fixed at $k_{T}$. Beyond period $T$, either the CEO grows the capital stock at rate $(1+r)$ or he pays dividends of $r$ times the capital stock, or he does some combination of growing the capital stock and paying dividends (for one transition period). This implies that if the IPO takes place in period $\tau$, the value of the equity issued is $\frac{k_{T}}{(1+r)^{T-\tau+1}}$.

In keeping with the spirit of our analysis, the CEO appropriates the proceeds from the offering entirely. The CEO chooses investment $k_{t}$ to maximize

$$
\theta\left(k_{\tau-1}\right)^{\gamma}\left[f\left(s^{C E O}\right)+g\left(s_{\tau}\right)\right]-\left(k_{\tau}-k_{\tau-1}\right)+\frac{k_{T}}{(1+r)^{T-\tau+1}}
$$

where $k_{T}$ depends on $k_{\tau}$ recursively through the investment decision of the going concern in the presence of equity: $k_{t}=\operatorname{Max}\left[k_{t}^{S B},(1+r) k_{t-1}\right]$. Now, the first-order condition for CEO's investment is given by

$$
\theta\left(k_{\tau-1}\right)^{\gamma} g^{\prime} \frac{d s_{\tau}}{d k_{\tau}}-1+\frac{\partial}{\partial k_{\tau}}\left(\frac{k_{T}}{(1+r)^{T-\tau+1}}\right)
$$


Since the going-concern capital grows at least at the rate $r$ before date $T$,

$\frac{\partial}{\partial k_{\tau}}\left(\frac{k_{T}}{(1+r)^{T-\tau+1}}\right) \geq 0$. Hence, the CEO at the time of IPO has a (weakly) greater incentive to invest (for any level of capital stock) compared to the second-best in absence of equity. This is because a higher end-of-period capital stock also increases the proceeds he gets from the IPO. In a sense then, the ability to "sell" the firm lengthens the CEO's horizon and gives him the incentive to invest more.

We summarize this discussion in the following proposition:

\section{Proposition 3:}

(i) Once the firm goes public and before reaching steady state, the firm's capital stock is always (weakly) higher than in the absence of outside equity.

(ii) The steady state capital stock of the public firm can be greater or less than the first best steady state capital stock.

IPO and Investment Growth: An example

Now let us consider a private firm whose CEO decides to take it public at $\mathrm{t}=10$, after it has reached (its private) steady state. ${ }^{16}$ In its private steady state, $k_{t}=0.0108$. Figure 4 a shows that in the period of the IPO, $k_{10}^{I P O}=0.285$. Clearly, the IPO has boosted investment substantially (and also managerial effort). The CEO would have little incentive to set this level of capital stock, were it not for the added incentive coming from the extra equity value he can raise through the IPO if he ups investment. Figure $4 \mathrm{~b}$ shows that once the high level of capital is achieved in the IPO stage, capital continues to grow sharply (in a convex manner) until it hits a growth rate equal to the return on idle capital $(r)$. Figure 4c illustrates that in this "growth phase", the firm pays outside equity only in capital and there are no cash dividends. What is the current manager or

\footnotetext{
${ }^{16}$ The parameters for this example are the same as before with $\theta^{\mathrm{SS}}=0.2$.
} 
future CEO's utility over this growth phase? Figure 4d plots this utility net of the effort incurred in learning as a manager. At the IPO stage and in the initial growth phase, this net utility $(U(k))$ rises steadily but declines sharply once capital grows to a level where diminishing returns to scale kick in. Once the utility reaches the reservation level of zero, each current CEO cannot grow capital any further (Figure 4b) without violating his manager's participation constraint (Figure 4d) and thus is forced to pay outside equity in the form of cash dividends (Figure 4c). The firm thus switches from its extraordinary growth phase to steady-state capital with stable cash dividends.

What is it that the IPO does to make a small stagnant firm explode with energy? Interestingly, it is not the financing. One reason why the firm expands is the IPO changes the CEO's investment incentives in the period of the IPO. But this would not be enough for sustained growth, for in the absence of outside equity, both capital stock and effort would subsequently decline to the steady state. Outside equity prevents such decline in an interesting way; Subsequent CEOs are required to compensate outside equity, but allowed to defer payment by building additional capital stock. This immediately alters the investment incentives of future CEOs, ensuring also that managerial effort remains high. As a result, the IPO moves the firm to a better equilibrium.

\section{Control rights}

It is noteworthy that even with crude control rights, outside equity has such an influence on the firm's growth path. Indeed, in our framework, outside equity's control rights are irrelevant so long as the firm is growing its capital stock at a rate greater than $r$. It may well be then that outside equity has value at that early stage even if its control rights are weak to the point of nonexistence, so long as it will acquire them eventually. And as processes become more stable and well-defined, and as management become more professional and standardized (see Hellman and Puri (2002)), outside equity will acquire the capacity to threaten to replace management. Thus 
internal governance may be sufficient to preserve substantial firm value initially, and when it weakens, external governance may have become sufficiently developed to add support.

Perhaps then this also explains why firms in emerging markets can issue outside equity, even when minority shareholder rights are currently poorly protected; The firm's resources will keep growing because of the pressures from internal organization, and the control rights exercisable by outside equity over these resources will improve over time as the country develops, and as firms become more clearly structured. These will eventually allow equity to be paid, and hence give it value long before equity protection is in place.

\subsection{Relaxing Assumptions.}

We have assumed that the CEO appropriates all the residual cash flow, that he owns no equity, and that there are no secondary equity issuances. Let us relax all three assumptions at the same time. Let the CEO gets $\beta$ of the cash flows left after investments and dividend payments.

Let us also assume that the CEO can appropriate $\beta_{E}$ of the cash flows from any secondary equity issue, with the remaining being dissipated (we will allow for the possibility that $\beta_{E}=\beta$, though it may be lower since the proceeds from an equity issuance can be tracked through various accounts and may be harder to alter than revenues or costs). Furthermore, let the CEO own a share $\omega$ of the existing stock.

First note that, as shown earlier, before steady state is reached, $k_{t}=\operatorname{Max}\left[k_{t}^{*},(1+r) k_{t-1}\right]$. where $k_{t}^{*}$ is the value that the CEO would have chosen "naturally" (see below) and $k_{t}$ is the capital stock that is actually chosen.

There are two more details we need to pin down before we can determine the value of equity. First, if $k_{t}^{*}>(1+r) k_{t-1}$, the CEO effectively overpays existing equity. He could pay existing equity exactly $(1+r) k_{t-1}$ if he issued an additional $k_{t}^{*}-(1+r) k_{t-1}$ of equity. The secondary equity offering will "dilute" the rights of existing equity because equity holders 
collectively will still have claim only to the capital stock, which is unchanged by the secondary equity issuance. The CEO will dilute existing equity if the fraction of cash flows he can appropriate from a secondary issuance, $\beta_{E}$, exceeds his share of the existing equity, $\omega$. In that case, the value of existing equity will be $(1+r) k_{t-1}$ at the end of the period, and the CEO will set

$$
k^{*} \in \underset{k}{\arg \max } \beta\left[\theta_{t}\left(k_{t-1}\right)^{\gamma}\left[f\left(s^{C E O}\right)+g\left(s_{t}\right)\right]-\left(k-k_{t-1}\right)\right]+\beta_{E}\left[k-(1+r) k_{t-1}\right]+\omega k_{t-1}^{E}
$$

Note that the ability to issue secondary equity reduces the opportunity cost of an additional dollar of capital investment to the CEO to $\beta-\beta_{E}$. Essentially, by committing to leave behind more capital, the CEO can also raise more secondary equity, so the "personal" cost of capital is simply the difference in appropriability between the two. Thus capital investment goes up relative to the situation without outside equity, even ignoring the fact that the incentive to pay dividends in capital rather than in cash will also push up capital investment.

More interesting, so long as the equity share the CEO owns, $\omega$, is less than his ability to appropriate, $\beta_{E}$, the equity share does nothing for $\mathrm{CEO}$ incentives to invest or refrain from appropriation. This is because the value of equity simply reflects the past value of capital stock.

It is only when the CEO's equity stake is high enough $\left(\omega>\beta_{E}\right)$ that the CEO stops diluting stock through secondary issuances. Now the value of equity can reflect future capital stock, much as it did in the case of the IPO discussed earlier, and the CEO may want to invest more when he owns more equity because in doing so, he enhances the value of equity.

\section{Internal Organization}

Thus far, we have examined the effects of capital structure on the incentives for internal governance. Let us now turn to ways the internal structure of the firm itself may affect internal 
governance. Internal organization typically will alter the sensitivity of the manager's effort to the CEO's investment, and will thus affect outcomes. We explore how.

\subsection{Altering the relative importance of the CEO and of the manager.}

We have seen that the relative importance of the CEO in producing cash flows, $\alpha$, affects the strength of internal governance. There is an interior optimal level of $\alpha$ which maximizes the net cash flows produced by the firm. $\alpha$ can be altered by changing the responsibilities of the CEO and the manager. For instance, if $\alpha$ is too high, implying the CEO takes on too much responsibility and leaves too little to subordinates, as is typical with many small firms, more tasks can be devolved to subordinates. Indeed, one of the roles of a venture capitalist might be to "professionalize" the firm (see Hellman and Puri (2002)) by bringing in professionals and decentralizing more of the founder's functions to them. Not only does this allow more external control of the firm, it can also lead to better internal control.

\subsection{Probability of promotion and firm size.}

We have assumed that the manager is fully assured of being promoted next period, and is the sole possible successor. Furthermore, we have assumed that no additional managers are needed as the firm's capital stock grows. What if, instead, more managers are needed as the firm's capital stock grows, and each manager's chances of promotion fall proportionately?

Suppose therefore that $N\left(k_{t}\right)$ managers are needed to produce with $k_{t}$ of capital stock and each manager's chance of getting the CEO's rents are $\frac{1}{N\left(k_{t}\right)}$, with $N^{\prime}>0 .{ }^{17}$ Modifying the manager's maximization problem in (1.6) and following some simple algebra, we have $\frac{d s_{t}^{S B}}{d k_{t}}=\frac{-f^{\prime}}{f^{\prime \prime}}\left[\frac{\gamma}{k_{t}}-\frac{N^{\prime}}{N}\right]$. This has to be positive for the current CEO to want to invest to motivate

\footnotetext{
${ }^{17}$ We assume other managers leave when they do not get the top job. The issue of how the CEO is selected and whether the Board can extract rents from managers when appointing one to the job is interesting, but left to future research.
} 
effort, and will be the case if $\gamma>\frac{N^{\prime}}{\frac{N}{k_{t}}}$, that is, if the marginal rate of growth of managers with additional capital stock is significantly less than the average managers per unit of capital. Put differently, if there are scale economies in management ( $N$ is concave so the number of managers does not increase as fast as the capital stock), then internal governance can still have salutary effect on incentives because, even though a larger capital stock means more managers, the associated rents grow disproportionately compared to the number of managers who expect to share it. But if, for example, there are scale diseconomies in management ( $N$ is convex), then internal governance becomes unable to provide the CEO incentives for investment beyond a certain level of capital stock - managers see too little possibility of future rents to be motivated by CEO investment, and consequently the CEO does not invest. This will limit the size of the firm.

Interestingly, the possibility that once the firm reaches a certain size, managers may get demotivated by additional investment, suggests another rationale why the CEO may start paying outside equity in cash dividends rather than in more investment. Our model makes it clear that the reason for the CEO to invest is not just to pursue growth, but also to motivate employees. The switch to cash dividends in our model could be a response to the second incentive no longer being operative (coming here from the effort response to additional investment rather than from the participation constraint, as earlier).

\subsection{Promotion Tied to Effort}

In the case discussed above, one manager's promotion was as likely as another's, independent of the effort she exerted. What if a manager is more likely to get promoted if she exerts more effort, while if she does not exert much effort, it will be easier for the board to find a comparable replacement outside? 
To see how this would affect our results, let us go back to the case of one manager, but let her be promoted to CEO only with probability $p\left(s_{t}\right)$, where $p^{\prime}>0$. Again, modifying her maximization problem in (1.6) and simplifying, we get $\frac{d s_{t}^{S B}}{d k_{t}}=\frac{-\gamma}{k_{t}\left(\frac{p^{\prime}}{p}+\frac{f^{\prime \prime}}{f^{\prime}}\right)}$. The CEO can provide more incentives for effort through investment if the right hand side is high. Comparing with (1.8), and recognizing the first term in the parentheses in the denominator is positive while the second is negative, we see that the firm can offer the best incentives for the CEO to invest if $\frac{p^{\prime}}{p}$ reaches its highest positive value (but below $\frac{f^{\prime \prime}}{f^{\prime}}$ in magnitude).

Consistent with intuition, the manager's effort will be more sensitive to CEO investment if her chances of capturing the future rent associated with the investment also increase in effort. Therefore, for any given probability of promotion, $p$, making promotion sensitive to effort will increase the strength of the internal governance effect. Conversely, any form of succession planning, which forces a high $p$ while reducing $p^{\prime}$, would tend to diminish the importance of this effect. $^{18}$

\subsection{Labor Market, Reservation Wage, and Entry}

Suppose now that the firm is in a competitive labor market where it has to hire the manager. It will have to pay the manager her reservation utility, $\bar{u}$. Thus far, we have assumed future rents are more than enough to compensate for the (zero) reservation utility. What if the reservation wage is positive, implying the firm has to attract the manager away from other lucrative sources of employment, and that the manager's anticipated future rents at the secondbest investment level are below the reservation wage. The CEO has a choice of paying for the

\footnotetext{
${ }^{18}$ The sensitivity comes from comparing the effect of an increase in effort with the effect of an increase in investment, which is why $p^{\prime}$ is scaled by $p$. A possible extension would be to examine the effects of an internal tournament between managers on $\mathrm{CEO}$ incentives to invest.
} 
shortfall of future rents through a greater cash wage $w_{t}$ or through greater investment (which will give the manager greater future rents). To explore this, note the CEO's maximization problem is

$$
\begin{gathered}
\max _{k_{t}, w_{t}} \theta_{t}\left(k_{t-1}\right)^{\gamma}\left[f\left(s^{C E O}\right)+g\left(s_{t}\right)\right]-\left(k_{t}-k_{t-1}\right)-w_{t} \\
\text { s.t. } \frac{1}{1+r}\left[\theta_{t+1}\left(k_{t}\right)^{\gamma}\left[f\left(s_{t}\right)+g\left(s_{t+1}\right)\right]-\left(k_{t+1}-k_{t}\right)\right]-s_{t}+w_{t} \geq \bar{u} \\
\text { where } s_{t} \in \underset{\hat{s}_{t}}{\arg \max } \frac{1}{1+r}\left[\theta_{t+1}\left(k_{t}\right)^{\gamma}\left[f\left(\hat{s}_{t}\right)+g\left(s_{t+1}\right)\right]-\left(k_{t+1}-k_{t}\right)\right]-\hat{s}_{t}
\end{gathered}
$$

Setting up the Lagrangian and taking the partial w.r.t. $k_{t}$, we get

$\theta_{t}\left(k_{t-1}\right)^{\gamma} g^{\prime}\left(s_{t}\right) \frac{d s_{t}}{d k_{t}}-1+\lambda \frac{1}{1+r}\left[\theta_{t+1} \gamma\left(k_{t}\right)^{\gamma-1}\left[f\left(s_{t}\right)+g\left(s_{t+1}\right)\right]+1\right]($ where as in the section on outside equity, derivatives of managerial utility with respect to $s_{t}$ and $k_{t+1}$ are zero by the Envelope Theorem). This means that we must have

$$
\lambda=\frac{1-\theta_{t}\left(k_{t-1}\right)^{\gamma} g^{\prime}\left(s_{t}\right) \frac{d s_{t}}{d k_{t}}}{\frac{1}{1+r}\left[\theta_{t+1} \gamma\left(k_{t}\right)^{\gamma-1}\left[f\left(s_{t}\right)+g\left(s_{t+1}\right)\right]+1\right]}
$$

The numerator in this expression is the cost to the CEO of the marginal unit of investment - note that this is less than 1 because the CEO obtains some benefits from the manager's consequent greater effort. Indeed, the numerator is zero at the unconstrained optimal. The denominator is the incremental rent the $\mathrm{CEO}$ generates for the manager next period through an additional unit of investment today. So if $\lambda$ is less than 1 , the CEO can generate more than a dollar of present value of rent for the manager tomorrow by incurring an incremental dollar of net investment cost today. Clearly, he would then prefer "paying through investment" than paying through cash, and would therefore exceed the investment he would make in the absence of a binding reservation wage. 
The alternative to paying the manager through investment is to pay through current wage, $w_{t}$. Differentiating the CEO's Lagrangian w.r.t. $w_{t}$, we find the CEO wants to increase the current cash wage if $\lambda>1$. Finally if $\lambda$ starts out less than 1 , as the CEO pushes investment higher $\lambda$ could reach 1 (from below) before the CEO has met the reservation wage. In that case, he will pay part in investment and the remainder in cash wages.

In sum then, if the CEO cannot meet the manager's reservation wage with the promise of rents at the unconstrained second best optimal, she will have an incentive to invest above that today so as to generate the "currency" with which to pay the current manager her reservation wage. This is over and above any investment intended to elicit managerial effort. This then suggests that the need to entice managers to participate in the firm today may offer the CEO greater incentive to invest for the future.

More generally, new recruits to the typical firm in the industry anticipate they will get future rents and thus are willing to settle for low initial salaries. To the extent that they see the CEO compromising the future, they will demand additional compensation, which can reduce the appropriable cash flows to the CEO substantially. Thus the CEO of a firm which requires a steady substantial intake of new entrants - either because its hiring in the past has been staggered or because it is on a fast growth path currently - will have strong incentives to not compromise the future, especially if the new entrants contribute quickly to the bottom line.

\section{Discussion and Conclusion}

We have taken a simple model, indeed a caricature of managerial behavior, and taken it to its logical conclusions. Top management is both myopic and self interested, and the board ineffective. Yet, considerable value is preserved in the organization because of the need for top management to motivate younger managers who are needed to generate cash flows. Bottom-up governance could play an important role. Indeed, a characteristic of many self-governing human 
capital intensive organizations is that substantial rents are concentrated at the top, for example among partners. The watchful eyes of subordinates, who hope to gain access to those rents, can keep partners from milking those rents excessively as they age.

If internal governance is an important factor in a number of corporations and countries, it is worth considering whether the move towards ever-greater shareholder rights, public disclosure, and minority investor protection is always a good thing. In a second-best world, internal governance may reach where external governance cannot. But if the board, myopically exercising its functions, or forced by laws protecting investors, limits rents at the top, it might dissuade subordinates from focusing on the long term, and taking actions to dissuade egregious CEO misbehavior. Greater external governance may stunt internal governance. Of course, this is not an attempt to justify any and all payments to CEOs, only a comment that payments should be viewed from a broader perspective of trading off internal and external governance.

Many commentaries (see, for example, Baker and Wruck, 1988) suggest that the LBO partnership's forte is not ever more intrusive micromanagement. Instead, it loads the firm up with debt, and gives top management considerable rents if they are able to pay down the debt and create value. If in addition to a motivated CEO, senior and middle management are motivated, not just by the prospect of current pay but by the prospect of participating eventually in the enormous rents at the top, it creates strong incentives for exercising internal governance. Thus the strength of going private transactions could, in part, be seen as their ability to reenergize internal governance, with external governance exercising just a crude control right.

Our model also suggests why it may be so hard for firms to shrink gracefully, and why it may make sense for a firm (like Philip Morris) in a mature, declining, industry like tobacco to diversify into a growing industry like food (by acquiring Kraft). If the firm were to stay in the declining industry, it would either have to overinvest or see a collapse of incentives, and worse, a collapse of the discipline imposed by internal governance. Rather than see the value destruction associated with such a decline, the second best option might be to "morph" into a new business. 
Large old firms don't just shut down, they transform themselves. What might be thought of as empire building by top management may be just a reaction to pressure from below. Indeed, Gort, Grabowski and McGukin (1985) find that unfavorable expectations of marginal returns to investment in existing businesses are an important spur to diversification, a finding consistent with the implications of our model, but also with others.

We would expect diversifying mergers by large firms in mature industries to be treated less harshly by the market than the typical diversification, with diversification being the least bad of the possible alternatives. There is some evidence of positive returns associated with conglomerate diversification programs (see Schipper and Thomson (1983)) for example, and with the conglomerate wave of the 1960s (see Matsusaka (1993) and Hubbard and Palia (1998)) but also strong evidence of a conglomerate discount (see, for example, Montgomery and Wernerfelt (1988), Lang and Stulz (1994), Berger and Ofek (1995)). Our explanation would be that diversification is better than the expected alternative of continued wasteful overinvestment in the existing business, but because the firm is not as good in the new business, or because of problems in managing an acquisition (see Rajan, Servaes and Zingales (2000) or Scharfstein and Stein (2000)), the diversified firm trades at a discount.

The breakdown of internal governance may also explain the increasing evidence of agency problems in financial firms in the ongoing crisis. When capital is relatively scarce and allocated based on detailed information available only within a firm, employees of financial firms are relatively immobile. Each one cares about the longer term future of their own firm, and has an incentive to monitor the actions of both colleagues as well as superiors. As capital becomes more widely available, though, employees become more mobile, and care less about the long term future of their firm. The internal pressure to worry about the long term becomes weaker, possibly leading to the kind of problems we have seen.

Finally, our paper suggests a rich interaction between the internal structure of firms, the strength of internal governance, and the need for any external governance. Internal governance 
may be quite effective in growing firms with young staff, where human capital is firm specific. By contrast, external governance may be much more important in mature firms in declining industries with aging staff where the required management skills are fairly generic. Countries like Japan that have had a rapid demographic transition may also have suffered as their old system of internal governance becomes less effective in a newer environment.

More generally, there is a rich vein of research to be mined in seeing the linkages between the internal organization of firms, internal governance, and external financing and governance. We have just touched the surface in this paper. More research clearly needs to be done. 


\section{References}

Allen, Franklin and Douglas Gale, 2000, Comparing Financial Systems, The MIT Press, Cambridge, Massachusetts.

Allen, Franklin, Carletti, Elena and Robert Marquez, 2007, "Stakeholder capitalism, corporate governance and firm value", Working Paper, University of Pennsylvania.

Atkeson, Andrew and Patrick Kehoe, 2005, "Modeling and measuring organizational capital", Journal of Political Economy, 113, 1026-1053.

Baker, George P., and Karen Wruck, 1989, "Organizational Changes and Value Creation in Leveraged Buyouts: The Case of O.M. Scott \& Sons Company", Journal of Financial Economics, $25,163-190$.

Berger, Philip, and Ofek, Eli, 1995, “Diversification's effect on firm value”, Journal of Financial Economics, 37 (January): 39-65.

Bolton, Patrick, Brunnermeier, Markus, and Laura Veldkamp, 2008, "Leadership, coordination and mission-driven management", Working Paper, New York University.

Boone, Peter, Breach, Alasdair, Friedman, Eric, and Johnson, Simon, 2000, "Corporate governance in the Asian financial crisis", Journal of Financial Economics, 58 (January): 141186.

Burkart, Mike, Gromb, Denis, and Panunzi, Fausto, 1997, "Large shareholders, monitoring, and the value of the firm", Quarterly Journal of Economics, 112 (August): 693-728.

Donaldson, Gordon, and Jay W. Lorsch, 1983, Decision Making at the Top, Basic Books, New York.

Dyck, Alexander, Morse, Adair, and Zingales, Luigi, 2007, "Who blows the whistle on corporate fraud?”, CEPR Discussion Paper No. DP6126, (February).

Fama, Eugene F., 1980, “Agency problems and the theory of the firm”, Journal of Political Economy, 88 (April): 288-307.

Fama, Eugene F., and Jensen, Michael C., 1983, "Separation of ownership and control", Journal of Law and Economics, 26 (June): 301-325.

Fama, Eugene F., and Jensen, Michael C., 1983, “Agency problems and residual claims”, Journal of Law and Economics, 26 (June): 327-349.

Fazzari, Steven, Hubbard, R. Glenn and Bruce Petersen, 1988, "Finance Constraints and Corporate Investment”, Brookings Papers on Economic Activity, 1, 141-195.

Fluck, Zsuzsanna, 1998, “Optimal Financial Contracting: Debt Versus Outside Equity”, Review of Financial Studies, vol 11, no 2 (summer 1998), pp 383-418. 
Gort, Michael, Grabowski, Henry, and McGuckin, Robert, 1985, "Organizational capital and the choice between specialization and diversification", Managerial and Decision Economics, 6 (March): 2-10.

Grossman, Sanford, and Hart, Oliver, 1986, "The costs and the benefits of ownership: a theory of vertical and lateral integration", Journal of Political Economy, 94 (August): 691-719.

Hansmann, Henry, 1996, The Ownership of Enterprise, Belknap Press, Cambridge.

Hart, Oliver, and Moore, John, 1990, "Property rights and the nature of the firm", Journal of Political Economy, 98 (December): 1119-1158.

Hellmann, Thomas, and Manju Puri 2002, "Venture capital and the professionalization of start-up firms: empirical evidence”, Journal of Finance, 57 (February): 169-197.

Hirschman, Albert, 1970, Exit, Voice, and Loyalty: Response to Declines in Firms, Organizations, and States, Harvard University Press, Cambridge.

Hubbard, Robert G. and Palia, Darius, 1999, "A reexamination of the conglomerate merger wave in the 1960s: an internal capital markets view", Journal of Finance, 54 (June): 1131-1152.

Jensen, Michael C., 1986, "Agency costs of free cash flow, corporate finance, and takeovers", American Economic Review, 76 (May): 323-329.

Jensen, Michael C., 1993, "The modern industrial revolution, exit, and the failure of internal control systems", Journal of Finance, 48 (July): 831-880.

Jensen, Michael, C., 2000, A Theory of the Firm: Governance, Residual Claims, and Organizational Forms, Harvard University Press, Cambridge.

Kaplan, Steven N., and Zingales, Luigi, 1997, "Do investment-cash flow sensitivities provide useful measures of financing constraints?", Quarterly Journal of Economics, 112 (February): $169-215$.

Kreps, David, 1990, "Corporate culture and economic theory", in James E. Alt and Kenneth A. Shepsle, editors, Rational Perspectives on Political Science, Cambridge University Press, New York.

Landier, Augustin, Sraer, David, and Thesmar, David, 2006, "Bottom-up governance”, working paper NYU.

Landier, Augustin, Sraer, David, and Thesmar, David, 2008, "Optimal Dissent in Organizations", forthcoming, Review of Economic Studies.

Lang, Larry H. P., and Stulz, René M., 1994, “Tobin's Q, corporate diversification, and firm performance", Journal of Political Economy, 102 (December): 1248-1280.

Lustig, Hanno, Syverson, Chad and Stijn Van Nieuwerburgh, 2008, "IT, corporate payouts and the growing inequality in managerial compensation”, Working Paper, New York University.

Mace, Myles, 1971, Directors: Myth and Reality, Harvard University, Boston. 
Matsusaka, John G., 1993, "Takeover motives during the conglomerate merger wave", RAND Journal of Economics, 24 (Autumn): 357-379.

Monks, Robert A. G., 2008, Corpocracy: How CEOs and the Business Roundtable Hijacked the World's Greatest Wealth Machine - And How to Get It Back, John Wiley \& Sons, New York.

Montgomery, Cynthia A., and Wernerfelt, Birger, 1988, "Diversification, Ricardian rents, and Tobin's Q", RAND Journal of Economics, 19 (Winter): 623-632.

Morck, Randall, Shleifer, Andrei, and Vishny, Robert W., 1990, "Do managerial objectives drive bad acquisitions?", Journal of Finance, 45 (March): 31-48.

Myers, Stewart C., 2000, “Outside equity”, Journal of Finance, 55 (June): 1005-1037.

Penrose, Edith T., 1959, Theory of the Growth of the Firm, John Wiley \& Sons, New York.

Prendergast, Canice, 1993, "The role of promotion in inducing specific human capital acquisition", Quarterly Journal of Economics, 108 (May): 523-534.

Rajan, Raghuram G., and Zingales, Luigi, 1998, "Power in a theory of the firm", Quarterly Journal of Economics, 113 (May): 387-432.

Rajan, Raghuram G., and Zingales, Luigi, 2001, "The firm as a dedicated hierarchy: a theory of the origins and growth of firms", Quarterly Journal of Economics, 116 (August): 805-851.

Rajan, Raghuram G., Servaes, Henri, and Zingales, Luigi, 2000, "The cost of diversity: the diversification discount and inefficient investment", Journal of Finance, 55 (February): 35-80.

Scharfstein, David S., and Stein, Jeremy C., 2000, "The dark side of internal capital markets: divisional rent-seeking and inefficient investment", Journal of Finance, 55 (December): 25372564.

Scharfstein, David, 1988, "Product-market competition and managerial slack", RAND Journal of Economics, 19 (Spring): 147-155.

Schipper, Katherine, and Thompson, Rex, 1983, "Evidence on the capitalized value of merger activity and acquiring firms", Journal of Financial Economics, 11 (April): 85-119.

Shleifer, Andrei, and Vishny, Robert W., 1997, “A survey of corporate governance”, Journal of Finance, 52 (June): 737-783.

Titman, Sheridan, 1984, "The Effect of Capital Structure on a Firm's Liquidation Decision," Journal of Financial Economics. 
Figure 2a: Convergence of investment in second-best to the steady state

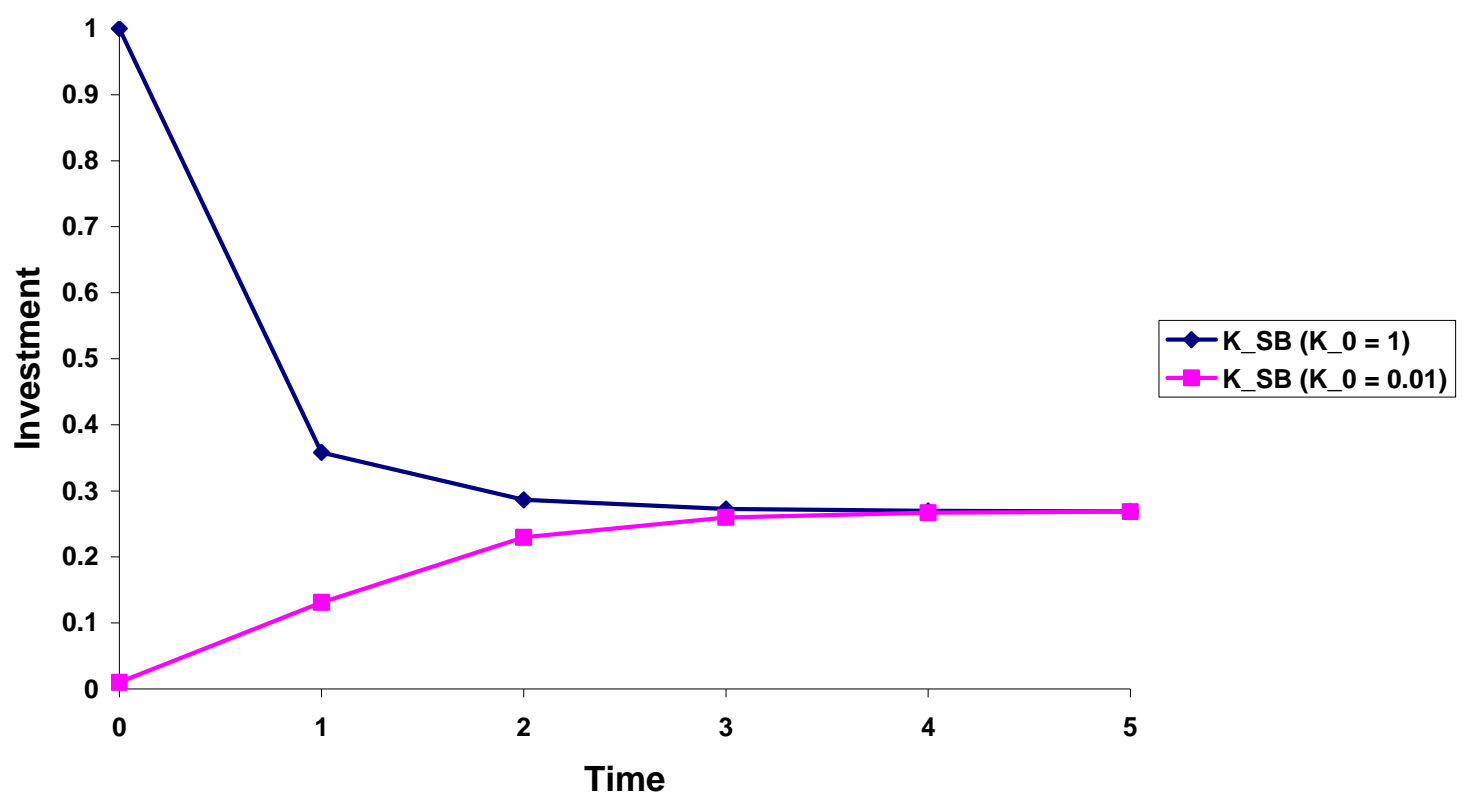

Figure 2b: Convergence of managerial learning in second-best to the steady state

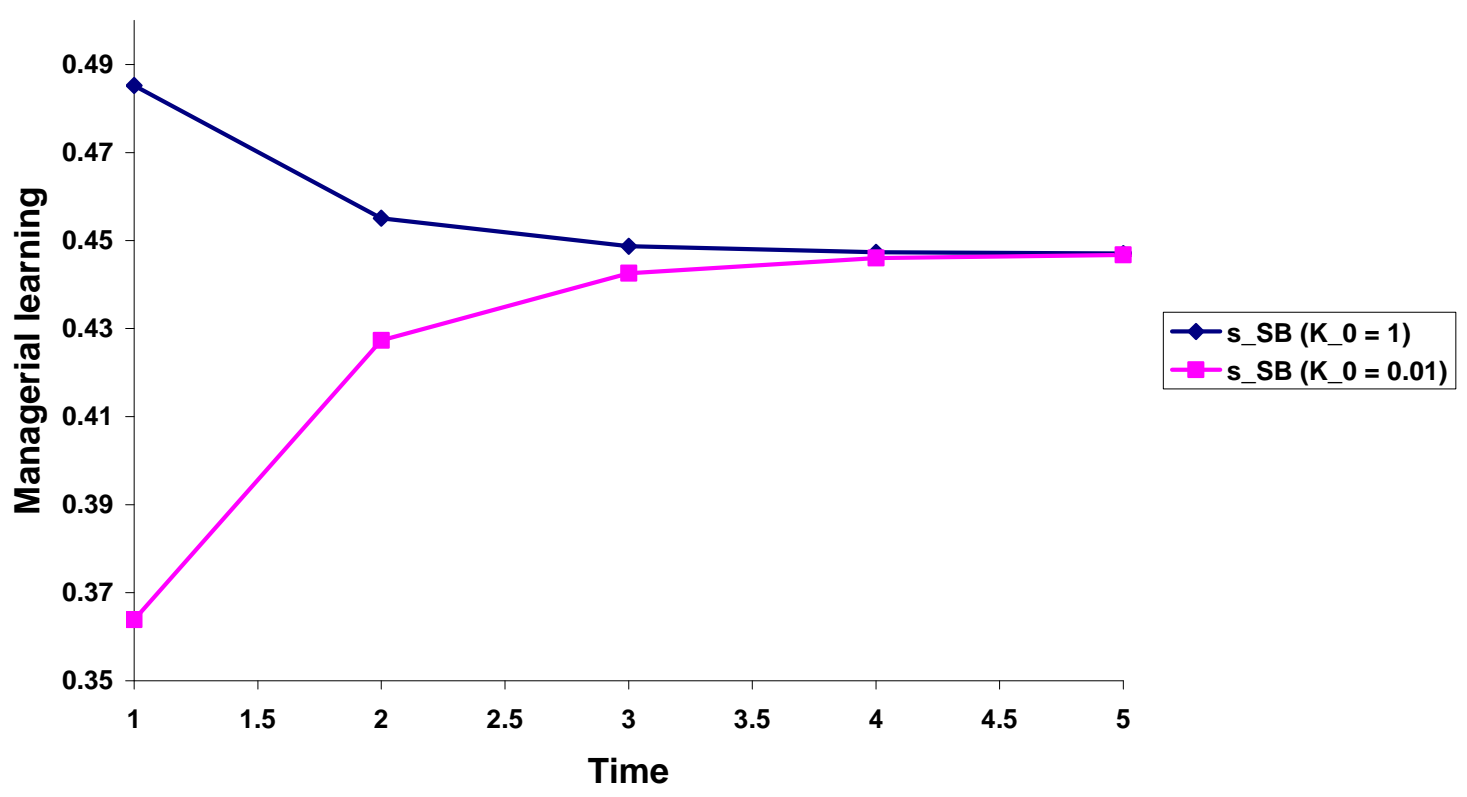


Figure 2c: Convergence of net cash flow in second-best to the steady state

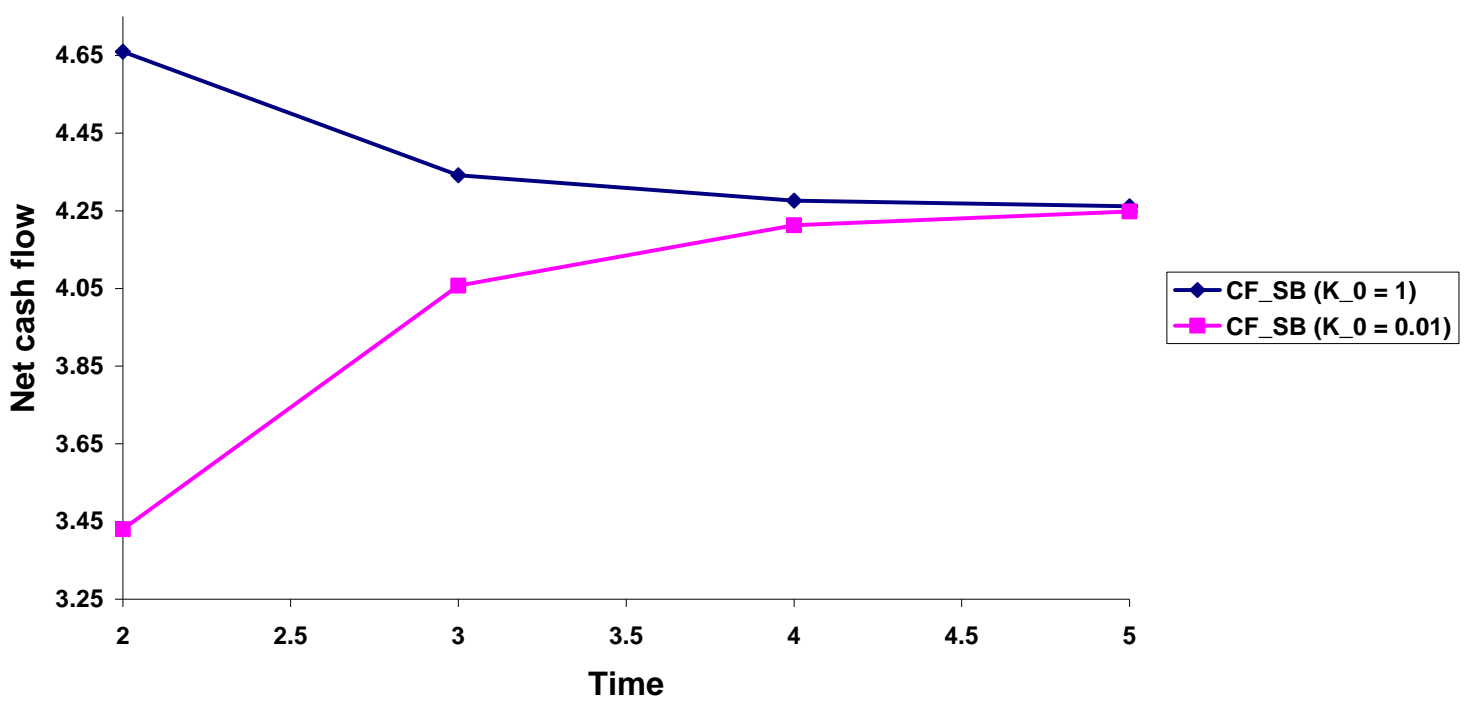

Figure 3a: Ratio of steady-state outcomes between SB and FB

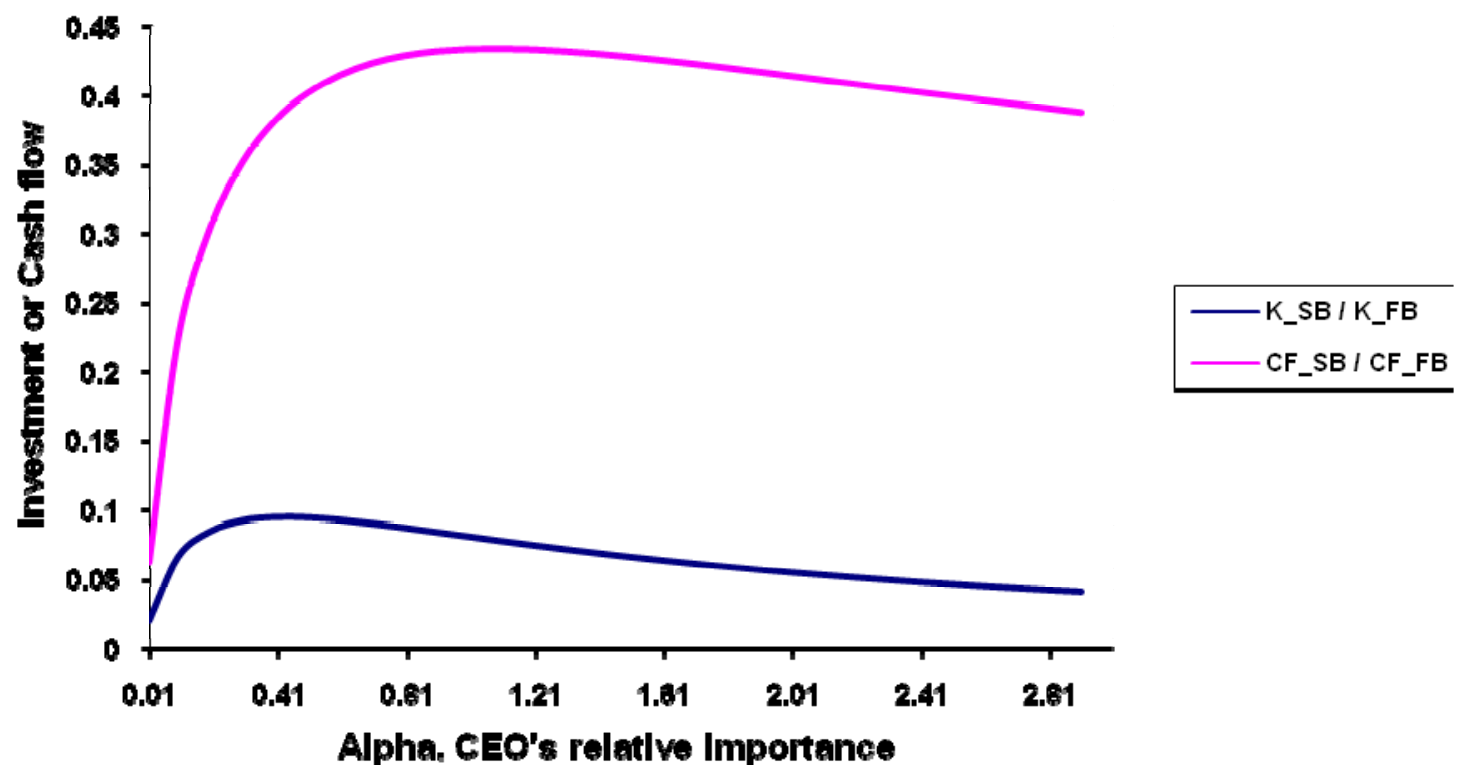


Flgure 3b: Sensitivlty of Investment to cash flow In a regression on cash flow and future condltions

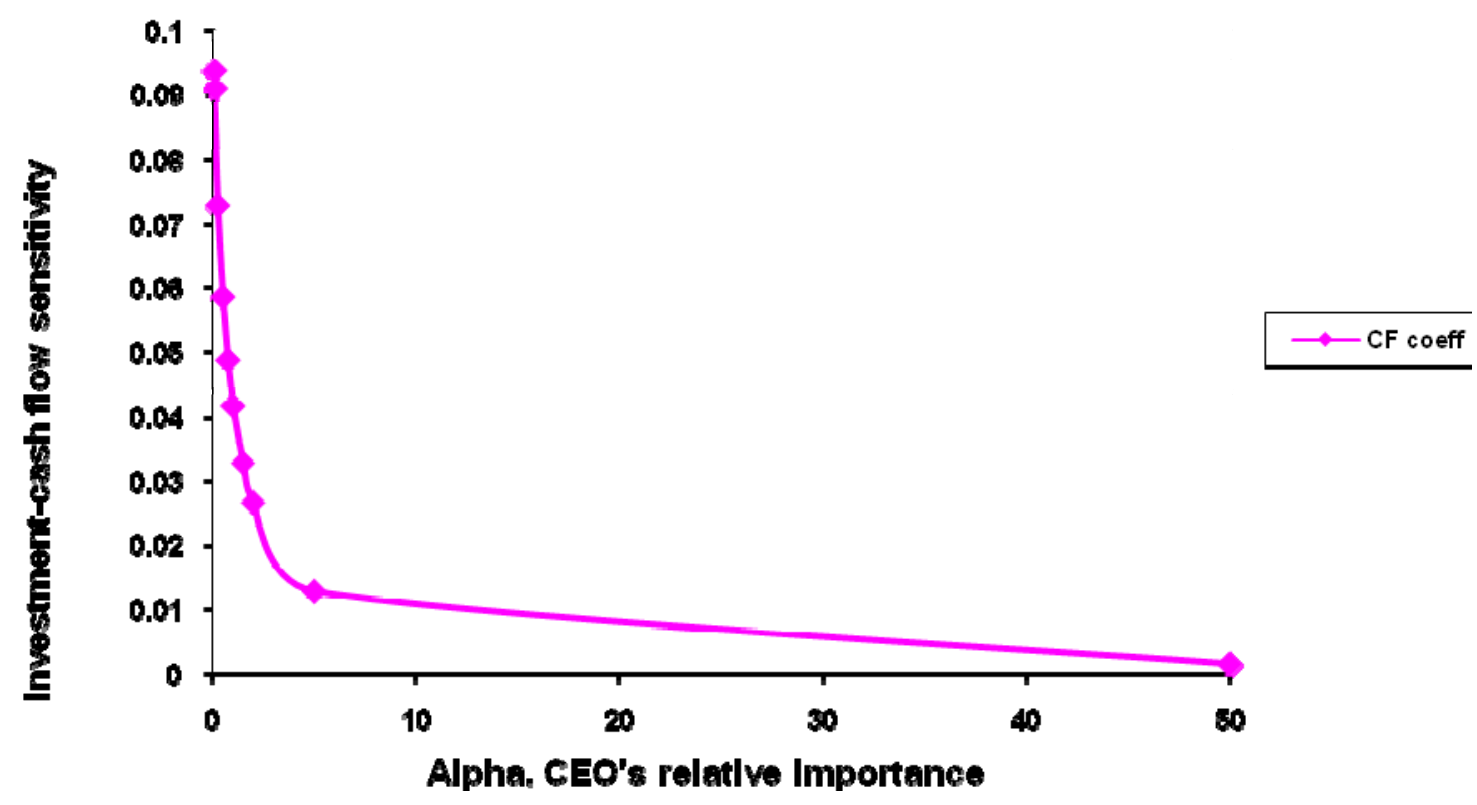

Flgure 3c: Sensitlvity of Investment to future conditlons In a regression on cash flow and future conditlons

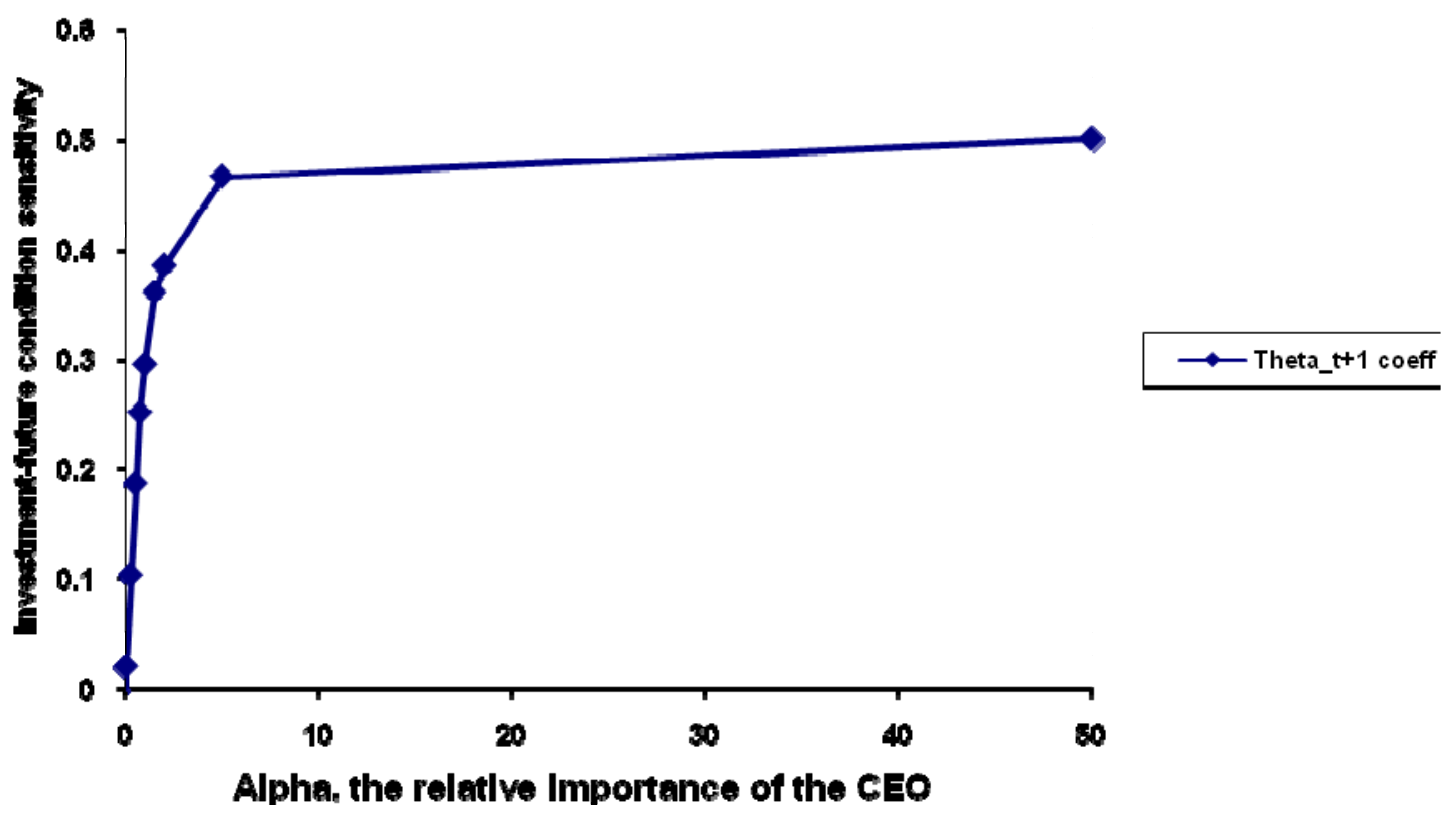


Figure 3d: Convergence of investment after temporary shock at $t=1$

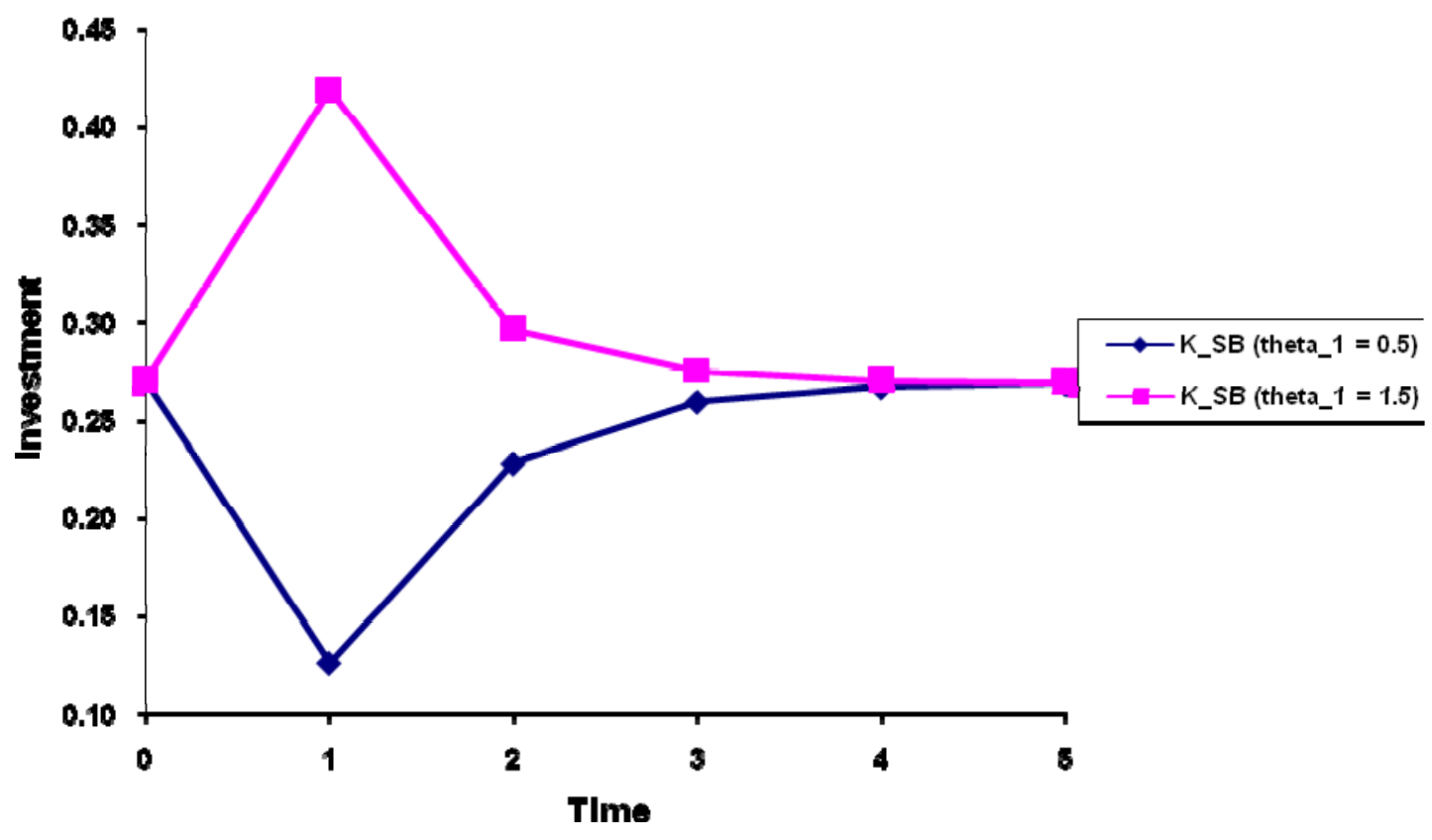

Figure 4a: Transient investment (IPO at t=10)

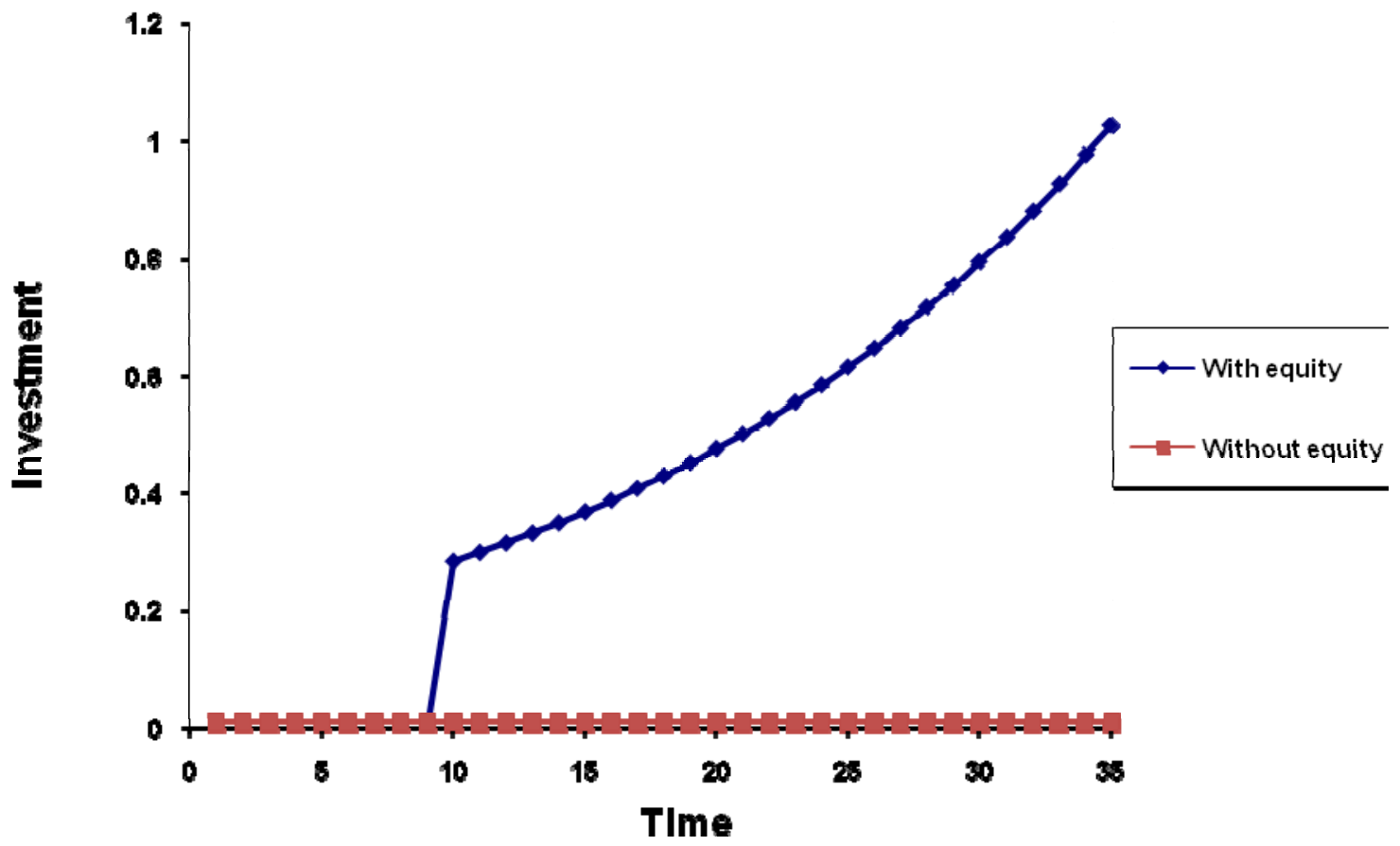


Figure 4b: Steady state investment with equity

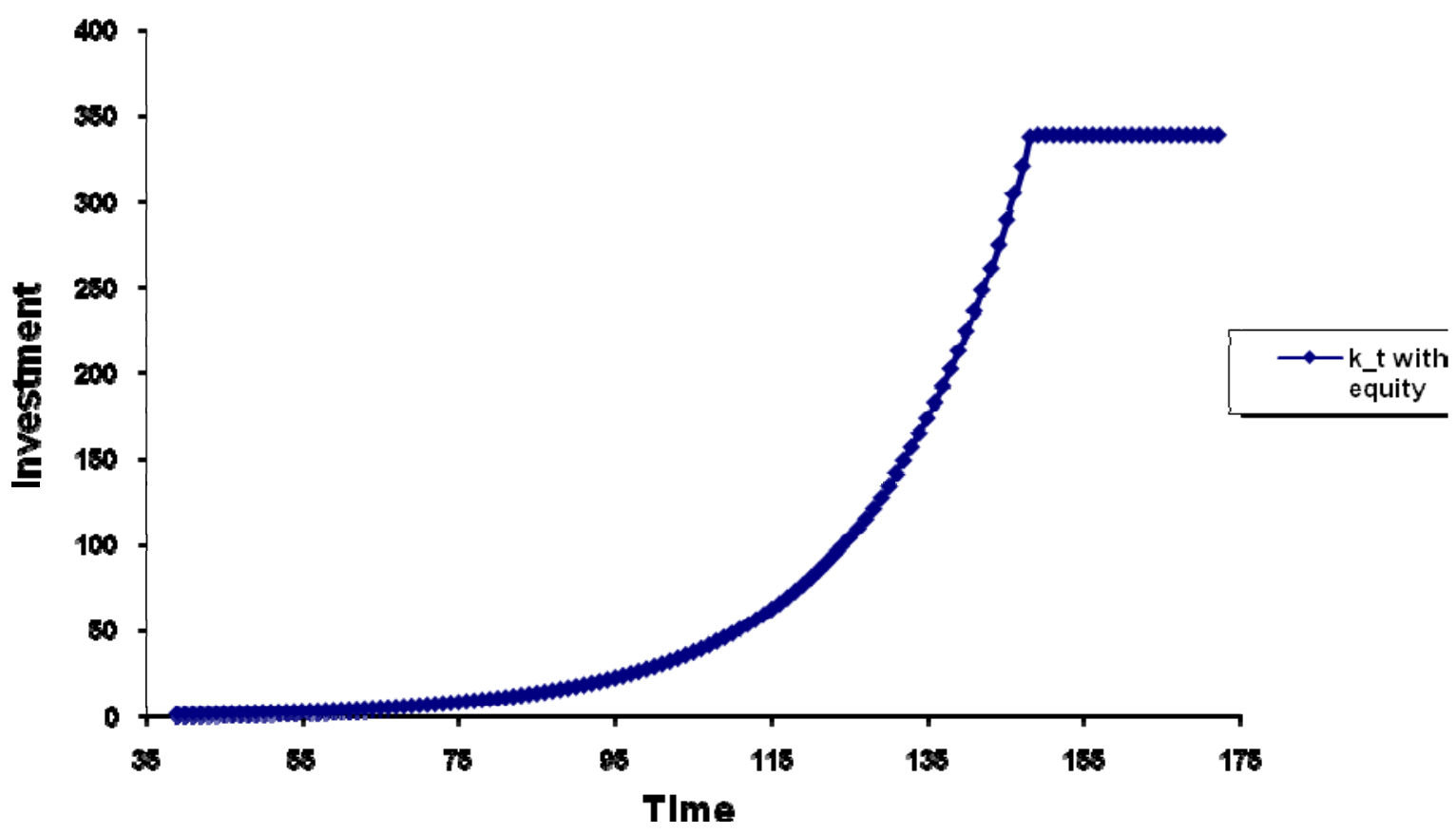

Figure 4c: Dividends to equity (IPO at $t=10$ )

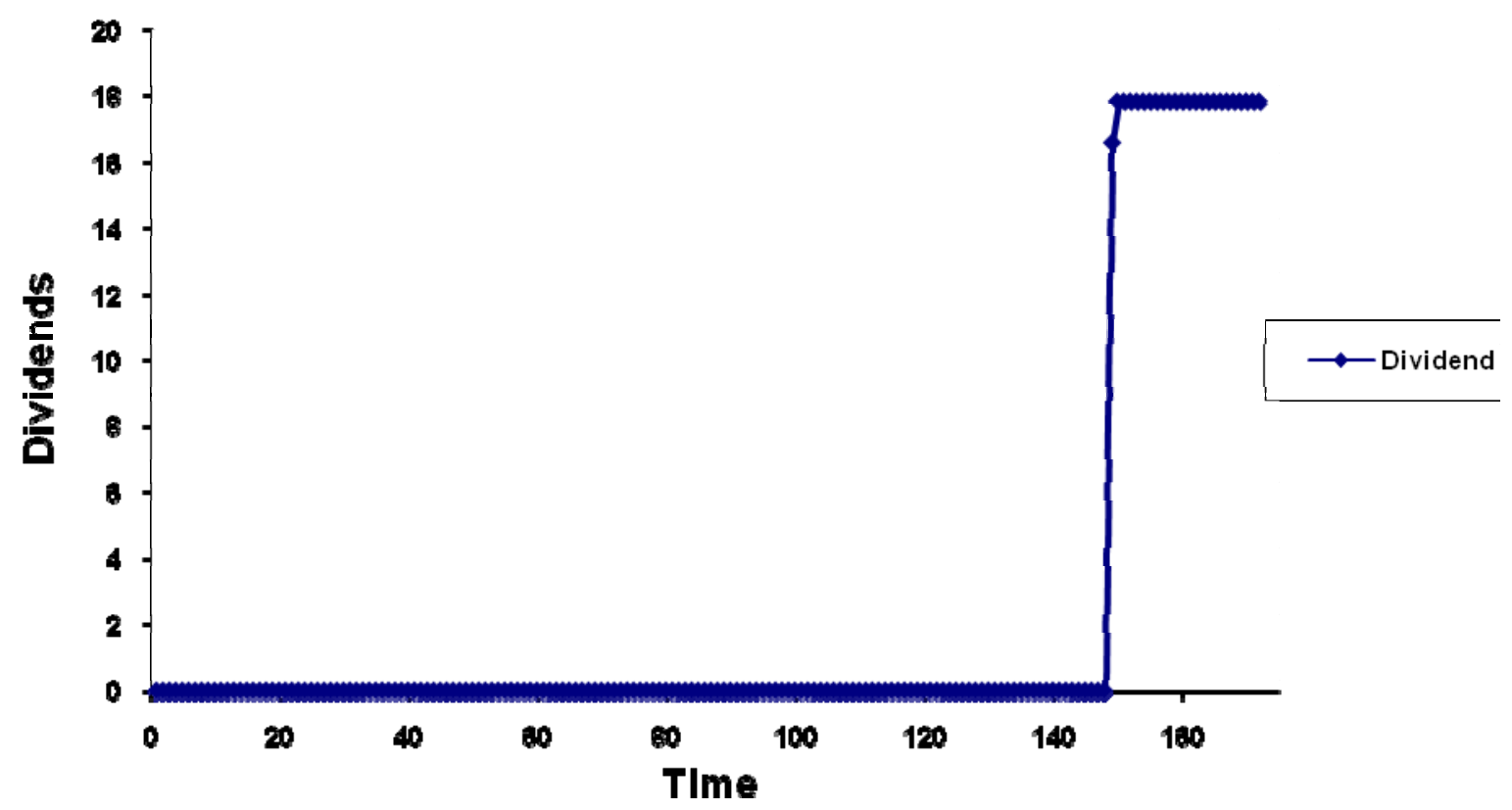



Figure 4d: CEO's net utility $(U(k))$ with IPO (at
$\mathbf{t = 1 0 )}$

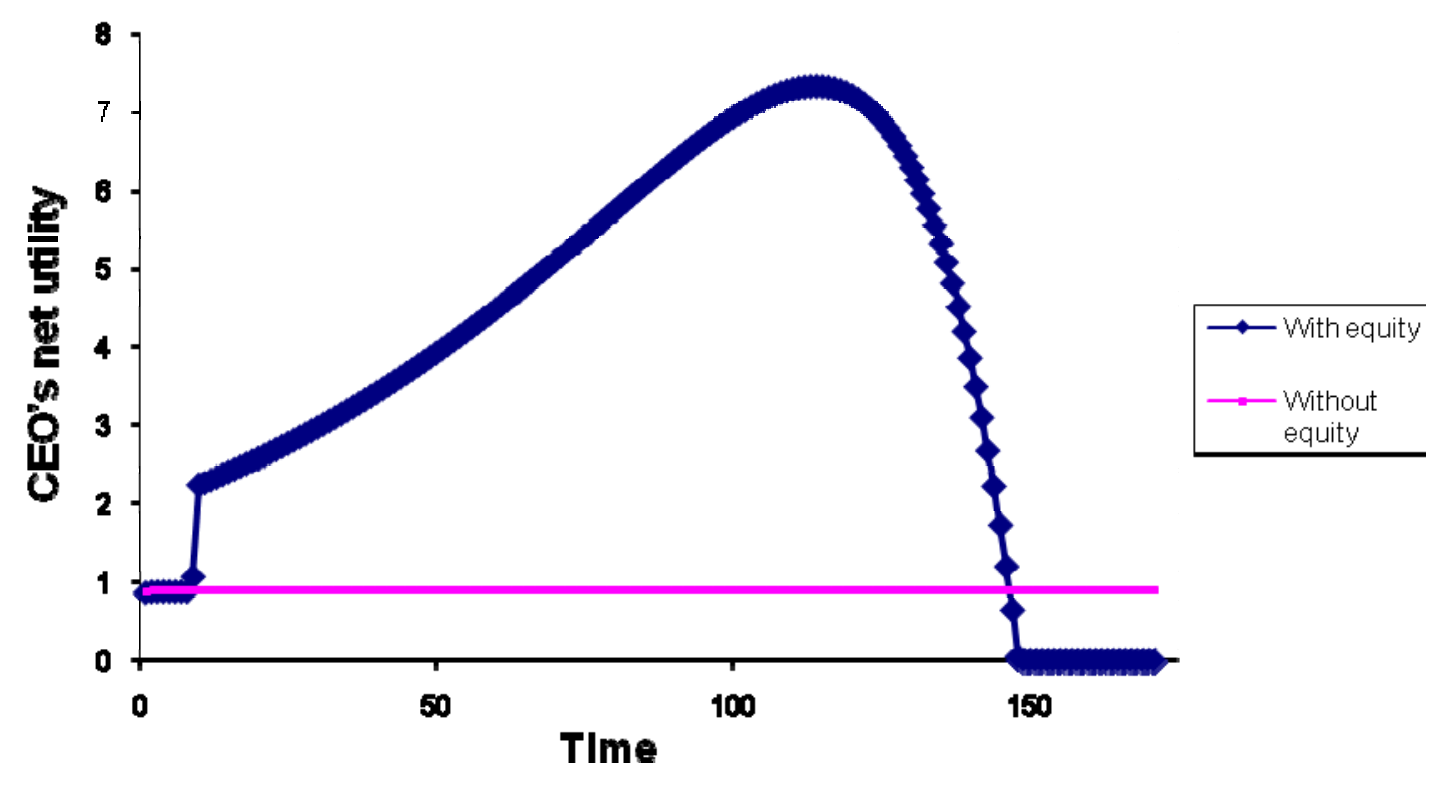

